\title{
Cellulose reinforced electrospun chitosan nanofibers bio-based composite sorbent for water treatment applications
}

\author{
Ilse Ileana Cárdenas Bates ·Éric Loranger · Aji P. Mathew· Bruno Chabot \\ Institut d'Innovations en Écomatériaux, Écoproduits et Écoénergies, Université du Québec à Trois-Rivières, 3351 \\ boul. des Forges, C.P. 500, Trois-Rivières, Qc G9A-5H7, Canada \\ Department of Materials and Environmental Chemistry, Stockholm University, Frescativägen 8, SE-10691 \\ Stockholm, Sweden \\ e-mail: Bruno.Chabot@uqtr.ca
}

\begin{abstract}
Electrospun chitosan-polyethylene oxide/TEMPO-oxidized cellulose (CS-PEO/TOC) bio-based composite was fabricated for the first time for water treatment applications. This new concept allows cellulose and chitosan to be combined in a simpler and efficient way, avoiding the use of harmful solvents, compared to previously published related work,. The "Sandwich-like" material is composed of a porous oxidized cellulosic fibers central core (TOC handsheet) and a thin layer of electrospun CS-PEO nanofibers on both sides of the core. Average diameters for CSPEO and TOC were $159.3 \pm 33.7 \mathrm{~nm}$ and $21.7 \pm 5.1 \mu \mathrm{m}$, respectively. Fourier Transform Infrared Spectroscopy (FTIR) was carried out on the bio-based composite. Results suggest that no covalent bonds are involved but rather electrostatic interactions occur which allows bonding of the electrospun nanofiber layers on TOC core and no delamination. CS-PEO electrospinning time was varied to study the effect of nanofiber's coating weight on strength, permeability and adsorption capacity of the bio-based material. Mechanical properties of the composite were improved over the electrospun nanofiber mat. The CS-PEO provides greater elasticity (strain \%) and the TOC provides a higher tensile strength to the material. However, tensile index was reduced by $48 \%$ with electrospinning time, while burst index was almost constant. The best conditions were achieved for $2 \mathrm{~h}$ electrospinning time. Under these conditions, a high permeable material $\left(290.13 \mathrm{~L} / \mathrm{m}^{2} \mathrm{hbar}\right)$ was developed. The adsorption capacity for $\mathrm{Cu}$ (II) ions reached up to $27 \%$ with only $12 \mathrm{mg}$ of chitosan onto the CS-PEO/TOC $(12.42 \mathrm{mg} / \mathrm{g})$. The data fit better to the pseudo-second order model, suggesting chemisorption as the main mechanism involved for copper adsorption. This study opens-up potential opportunities for the development of a robust material for wastewater applications at an industrial scale.
\end{abstract}

Keywords Bio-based reinforced composite adsorbent; Electrospun chitosan nanofibers; TEMPO-oxidized cellulose; Mechanical property; Water purification; Copper ions adsorption

\section{Graphical abstract}

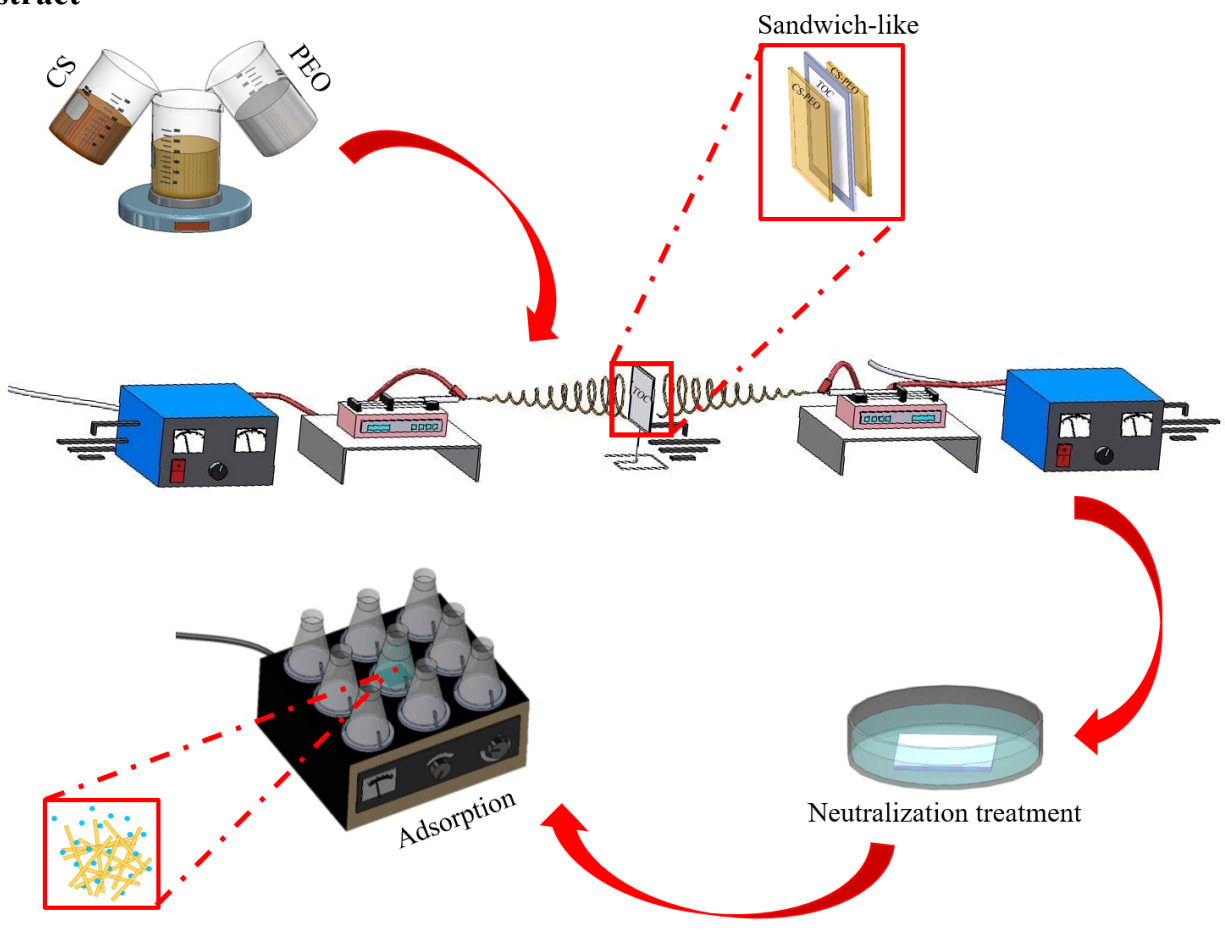




\section{Introduction}

Rapid industrialization and urbanization growth has led to an alarming pollution problem in the aquatic ecosystem, affecting the quality of life (Diagboya et al. 2014; Ranade and Bhandari 2017). Among the most dangerous pollutants, heavy metals are of great importance due to their high toxicity, non-biodegradability and carcinogenic effect (Amuda et al. 2016; Anastopoulos and Kyzas 2016; Liu et al. 2016a). Their accumulation in the environment is posing a serious treat to living systems. Therefore, the removal of these metals is very important for human health and environmental security. In this study, copper ions have been chosen as the target metal since their exposition to large doses produce weakness, insomnia, gastrointestinal diseases, DNA damages, cessation of menstruation, osteoarthritis and lethargy, etc... (Dragan et al. 2014; Amuda et al. 2016; Teow et al. 2018; Vardhan et al. 2019). Besides, it is a common toxic waste found in major manufacturing industries such as petroleum, mining, pesticides, pulp and paper, fertilizers, dye/textiles, among others (Sehaqui et al. 2014; Liu et al. 2016a; Ranade and Bhandari 2017; Vardhan et al. 2019) and also a common reference materials (Chen et al. 2017).

Various chemical and physical techniques such as ion-exchange, chemical precipitation, reverse osmosis, biological treatment, advanced oxidation and electrochemical methods have been applied to remove heavy metals from water (Tian et al. 2011; Abdullah et al. 2019; Vardhan et al. 2019). However, they are either costly or inefficient. Hence, other techniques have been studied to improve efficiency and to reduce costs. Nowadays, adsorption is generally considered as a promising technique due to its low cost, simplicity, possibility to reuse the adsorbent and high efficiency to remove heavy metals from aqueous effluents (Anastopoulos and Kyzas 2016; Sarkar and Adhikari 2018; Wang et al. 2018). In this technique, the choice of the most appropriate adsorbent is critical from both techno-economic feasibility and environmental points of view. In recent years, some efforts have been made toward the study of new bio-based material adsorbents (biosorbents) as they are renewable, unlimited and biodegradable (Paquin et al. 2013; Islam et al. 2014; Jiaping Paul Chen et al. 2016). Besides, these materials can be produced from industrial residues of biomass allowing them to be recycled. More recently, many publications have been reported on using chitosan or cellulose as a biosorbent material for multiple heavy metals as they are the two most abundant natural polymers in the world, they involve economical chemical reagents and they show great adsorption capacity towards heavy metals (Ahmad et al. 2015; Zhang et al. 2016). During the last few years, many researchers have demonstrated higher sorption capacities of chitosan/cellulose $(\mathrm{CS} / \mathrm{Ce})$ blends compared to results obtained with chitosan or cellulose films/membranes taken individually (Du and Hsieh 2009; Morgado et al. 2011; Aquino et al. 2018; Somsap et al. 2019). This is because despite the great adsorption capacity of chitosan, these media present low mechanical properties making them inadequate for industrial scale applications. Thus, addition of cellulose fibers as a reinforcing agent should improve the mechanical strength of the adsorbent material. Besides, in addition to amine $\left(\mathrm{NH}_{2}\right)$ and hydroxyl $(-\mathrm{OH})$ groups in chitosan, cellulosic fibers also have hydroxyl groups which facilitates the chelation with metal ions (Salihu et al. 2012). Some studies on copper adsorption (Sehaqui et al. 2014; Liu et al. 2016b; Zhu et al. 2017) using cellulosic fibers obtained through 2,2,6,6-tetramethyl-1-piperidinyloxy (TEMPO) mediated oxidation, have shown several advantages versus other types of modified cellulose (Jradi et al. 2012; Bideau et al. 2016). These advantages include the presence of carboxylate $\left(\mathrm{COO}^{-}\right)$groups, which also have a potential to retain metals ions or improve the crosslinking, giving greater potential physical resistance to the composite.

Chitosan and cellulose polymers have been combined into various shapes such as sponges, membranes, hydrogel beads, micro/nanospheres, flakes, coated fibers, textile assemblies, hollow fibers and electrospun webs (Salihu et al. 2012; Tetala and Stamatialis 2013). Among all of them, electrospun webs have received great consideration, as electrospinning is a simple and unique technique to obtain long nano/microfibers that provides a large surface area per unit mass and small pores. The higher surface area of nanofiber web improve adsorption rate compared to other material shapes (Tian et al. 2011; Devarayan et al. 2013; Wang et al. 2018). Briefly, during the electrospinning process, an electrically charged polymeric solution is ejected from a syringe tip as a continuous jet toward a collector. As the jet travels in air, the solvent evaporates allowing the formation of very thin fibers which are deposited on a metallic collector (Muthu Kumar et al. 2019; Xue et al. 2019). Polymers must previously be dissolved and properly mixed in order to get a homogeneous solution. However, in the case of chitosan and cellulose, these two biopolymers cannot be dissolved in a common solvent due to the presence of strong hydrogen bond in their molecular chains (H.P.S et al. 2016). To overcome this issue, several researchers (Du and Hsieh 2009; Salihu et al. 2012; Aquino et al. 2018; Li et al. 2018; Somsap et al. 2019) have used cellulose or chitosan derivatives such as Dibutyryl chitin and cellulose acetate with co-solvents systems such as Dichloromethane (DCM), Acetone, Acetic acid (AcOH) and Pyridine. Three other studies, (Devarayan et al. 2013; Phan et al. 2018; Wang et al. 2018) on the contrary, succeeded by blending chitosan with cellulose as such using a co-solvent system of Trifluoroacetic acid (TFA)/AcOH or $\mathrm{H}_{2} \mathrm{SO}_{4} / \mathrm{AcOH}$. Therefore, to date, there are very few reports on electrospun Chitosan/Cellulose composites. A list of these related publications is provided in Table 1. 
Table 1. Electrospun Chitosan/Cellulose composites and their applications

\begin{tabular}{|c|c|c|c|c|}
\hline Matrix polymers & Solvent system & $\begin{array}{c}\text { Mean fiber } \\
\text { diameters }\end{array}$ & Application study & Reference \\
\hline $\begin{array}{c}\text { Cellulose acetate/ Dibutyryl } \\
\text { chitin }\end{array}$ & Acetone/Acetic Acid & $30-350 \mathrm{~nm}$ & Unlisted & $\begin{array}{c}\text { (Du and } \\
\text { Hsieh 2009) }\end{array}$ \\
\hline Cellulose/Chitosan & $\begin{array}{c}\text { 1-Ethyl-3- } \\
\text { methylimidazolium acetate/ } \\
\text { Dimethyl sulfoxide }\end{array}$ & $\sim 200 \mathrm{~nm}$ & $\begin{array}{l}\text { Antistaphylococcal } \\
\text { activity for wound } \\
\text { healing }\end{array}$ & $\begin{array}{l}\text { (Miao et al. } \\
\text { 2011) }\end{array}$ \\
\hline Cellulose/Chitosan & $\begin{array}{l}\text { 1-ethyl-3- } \\
\text { methylimidazolium acetate }\end{array}$ & N/A & $\begin{array}{c}\text { Antibacterial activity } \\
\text { for wound healing } \\
\text { gauzes }\end{array}$ & $\begin{array}{l}\text { (Park et al. } \\
\text { 2011) }\end{array}$ \\
\hline Chitosan/Cellulose acetate & $\begin{array}{l}\text { Trifluoroacetic Acid/ } \\
\text { Dichloromethane }\end{array}$ & $450-650 \mathrm{~nm}$ & Unlisted & $\begin{array}{l}\text { (Salihu et al. } \\
\text { 2012) }\end{array}$ \\
\hline Cellulose/Chitosan & $\begin{array}{l}\text { Trifluoroacetic Acid/ } \\
\text { Acetic Acid }\end{array}$ & $\begin{array}{c}77 \pm 33 \mathrm{~nm}(\mathrm{Ce} \text { from } \\
\text { bamboo) } \\
82 \pm 44 \mathrm{~nm}(\mathrm{Ce} \\
\text { from cotton })\end{array}$ & Unlisted & $\begin{array}{l}\text { (Devarayan et } \\
\text { al. 2013) }\end{array}$ \\
\hline $\begin{array}{l}\text { Cellulose monoacetate/ } \\
\text { chitosan }\end{array}$ & Acetone/Glutaraldehyde & $1 \mu \mathrm{m}-2 \mu \mathrm{m}$ & $\begin{array}{l}\text { Immobilization of } \\
\text { proteases for } \\
\text { detergent and textile } \\
\text { industries }\end{array}$ & $\begin{array}{l}\text { (Demirkan et } \\
\text { al. 2018) }\end{array}$ \\
\hline $\begin{array}{l}\text { Poly (ethylene oxide)/ } \\
\text { chitosan/cellulose } \\
\text { nanocrystals }\end{array}$ & Acetic Acid & $\begin{array}{c}88 \pm 32 \mathrm{~nm}(5 \% \\
\mathrm{CNCs}) \\
71 \pm 32 \mathrm{~nm}(10 \% \\
\mathrm{CNCs})\end{array}$ & $\begin{array}{l}\text { Cell assay in cultures } \\
\text { 3T3 fibroplasts for } \\
\text { applications in tissue } \\
\text { engineering }\end{array}$ & $\begin{array}{c}\text { (Ridolfi et al. } \\
\text { 2017) }\end{array}$ \\
\hline *Chitosan/Cellulose acetate & $\begin{array}{l}\text { Trifluoroacetic Acid/ } \\
\text { Acetic Acid }\end{array}$ & $\begin{array}{l}122 \pm 35 \mathrm{~nm}(4 \% \\
\mathrm{CS}) \\
349 \pm 96 \mathrm{~nm}(6 \% \\
\mathrm{CS})\end{array}$ & $\begin{array}{l}\mathrm{As}(\mathrm{V}), \mathrm{Pb}(\mathrm{II}) \text { and } \\
\mathrm{Cu}(\mathrm{II}) \text { adsorption for } \\
\text { wastewater } \\
\text { purification }\end{array}$ & $\begin{array}{l}\text { (Phan et al. } \\
\text { 2018) }\end{array}$ \\
\hline $\begin{array}{l}\text { *Cellulose nanocrystals/ } \\
\text { Chitosan/Polyvinyl alcohol }\end{array}$ & $\begin{array}{l}\text { Acid acetic/ Thioglycolic } \\
\text { Acid/ Tetrahydrofuran / } \\
\text { Sulfuric Acid }\end{array}$ & $30-350 \mathrm{~nm}$ & $\begin{array}{c}\mathrm{Pb}(\mathrm{II}) \text { and } \mathrm{Cu}(\mathrm{II}) \\
\text { adsorption for } \\
\text { wastewater } \\
\text { purification }\end{array}$ & $\begin{array}{l}\text { (Wang et al. } \\
\text { 2018) }\end{array}$ \\
\hline $\begin{array}{l}\text { Chitosan nanoparticles/ } \\
\text { Ethylcellulose/Bacterial } \\
\text { cellulose sulfate membrane }\end{array}$ & Ethanol/Pyridine & $150-1000 \mathrm{~nm}$ & $\begin{array}{l}\text { Platet adhesion and } \\
\text { inflammatory } \\
\text { response for blood } \\
\text { compatibility }\end{array}$ & $\begin{array}{l}\text { (Li et al. } \\
\text { 2018) }\end{array}$ \\
\hline *Cellulose acetate/Chitosan & $\begin{array}{l}\text { Trichloroacetic } \\
\text { acid/dichloromethane }\end{array}$ & $\begin{array}{c}368 \pm 157 \mathrm{~nm}(15 \% \\
\mathrm{CS}) \\
992 \pm 343 \mathrm{~nm}(5 \% \\
\mathrm{CS})\end{array}$ & $\begin{array}{l}\text { Cd (II) adsorption for } \\
\text { wastewater } \\
\text { purification }\end{array}$ & $\begin{array}{l}\text { (Aquino et al. } \\
\text { 2018) }\end{array}$ \\
\hline $\begin{array}{c}\text { Chitosan/Cellulose acetate/ } \\
\text { gelatin/eugenol }\end{array}$ & Acetic Acid & $\begin{array}{l}156 \pm 17 \mathrm{~nm}(0.1 \% \\
\text { eugenol }) \\
288 \pm 77 \mathrm{~nm}(10 \% \\
\text { eugenol })\end{array}$ & $\begin{array}{l}\text { Antibacterial activity } \\
\text { for food packaging }\end{array}$ & $\begin{array}{l}\text { (Somsap et al } \\
\text { 2019) }\end{array}$ \\
\hline $\begin{array}{c}\text { *Chitosan/Polyethylene } \\
\text { oxide/ Phosphorylated } \\
\text { nanocellulose }\end{array}$ & Acetic Acid & $217 \pm 52 \mathrm{~nm}$ & $\begin{array}{l}\text { Cd (II) adsorption for } \\
\text { wastewater } \\
\text { purification }\end{array}$ & $\begin{array}{l}\text { (Brandes et } \\
\text { al. 2019) }\end{array}$ \\
\hline $\begin{array}{l}\text { *Chitosan/Phosphorylated } \\
\text { cellulose }\end{array}$ & Acetic Acid & $\begin{array}{c}372.3 \pm 82.1 \mathrm{~nm} \\
(\mathrm{CS}-\mathrm{PEO}) \\
21.5 \pm 3.7 \mu \mathrm{m} \\
(\mathrm{PCF})\end{array}$ & $\begin{array}{l}\mathrm{Cd}(\mathrm{II}), \mathrm{Cr}(\mathrm{VI}), \mathrm{Cu} \\
\text { (II) and } \mathrm{Pb}(\mathrm{II}) \\
\text { adsorption for water } \\
\text { treatment }\end{array}$ & $\begin{array}{l}\text { (Brandes et } \\
\text { al. 2020) }\end{array}$ \\
\hline Chitosan/Cellulose acetate & $\begin{array}{l}\text { Trifluoroacetic Acid/ } \\
\text { Dichloromethane/ Formic } \\
\text { Acid }\end{array}$ & $\begin{array}{c}88.14 \pm 0.27 \text { to } \\
129.00 \pm 0.18\end{array}$ & $\begin{array}{l}\text { Electrochemical } \\
\text { enzymatic biosensors }\end{array}$ & $\begin{array}{l}\text { (Yezer and } \\
\text { Demirkol } \\
2020)\end{array}$ \\
\hline
\end{tabular}

Note: *Application studies in wastewater treatment 
Moreover, most of them use toxic solvents, such as pyridine (carcinogenic), DCM (carcinogenic potential) and TFA that are also toxic. Also, as far as we know, only Phan et al. 2018, Brandes et al. 2020 and Wang et al. 2018 have studied the potential of electrospun Chitosan/Cellulose bio-based materials as an adsorbent for copper ions.

This study presents the development of a new original 3D structural assembly never reported in previous publications combining both chitosan and cellulose into a single adsorbent media. This assembly consist in fabricating an ecoresponsible "Sandwich-like" bio-based composite using a central core of TEMPO-Oxidized cellulose (TOC) fiber, coated on both sides by an ultrathin electrospun CS-PEO nonwoven mat layer. Extensive characterization revealed the unique surface properties of this bio-based composite, such as improved mechanical strength and permeability. Finally, yet importantly, we also found a potential use in this material as an adsorbent for copper ions in aqueous solutions.

\section{Experimental}

\section{Materials}

Chitosan powder (CS, deacetylation of 75 to $85 \%$, low molecular weight), Polyethylene oxide used as a co-spinning agent (PEO, $\mathrm{Mv} \sim 900,000)$, Acetic acid (AcOH, 99.7\%), Murexide ACS reagent and Copper (II) sulfate pentahydrate $\left(\mathrm{CuSO}_{4} \cdot 5 \mathrm{H}_{2} \mathrm{O}\right)$ were purchased from Sigma-Aldrich Chemical Company USA. TEMPO-oxidized cellulose fibers (TOC, $1700 \mathrm{mmol} / \mathrm{kg}$ ) were supplied by our laboratory. Sodium bicarbonate powder $\left(\mathrm{NaHCO}_{3}, 99 \%\right)$ and Ethylenediamine tetraacetic acid (EDTA, 99\%) were purchased from Omega Chemical Company USA. All chemicals were used without additional purification.

\section{Bio-based composite fabrication}

Standard handsheets at an oven dry (OD) weight of $60 \mathrm{~g} / \mathrm{m}^{2}$ were made with TOC fibers according to TAPPI Standard No. T $205 \mathrm{sp}-02$. Briefly, $8 \mathrm{~L}$ of a pulp fiber suspension at a consistency of $0.3 \%$ was prepared from an accurate weight of ovendried TOC fiber sample. From this pulp suspension, the required volume to make a $1.2 \mathrm{~g}(\mathrm{OD})$ handsheet was sampled and poured into a NORAM handsheet machine where the sheet is formed by filtration through a 150 mesh (approx. $100 \mu \mathrm{m}$ opening size) wire screen (TAPPI Standard No. T-205 sp-02. Seven handsheets were then made following the same process. Afterwards, the TOC handsheets were pressed as described in the TAPPI standard method. Then, they were placed into special drying rings to prevent sheet shrinkage and dried overnight in a conditioning room at $23^{\circ} \mathrm{C}$ and $50 \%$ of relative humidity (TAPPI Standard No. 402 -sp-03). Subsequently, a TOC handsheet was fixed to the metal collector of the electrospinning unit. Then, a CS-PEO solution was electrospun on both sides of the TOC handsheet to form a "Sandwich-like" composite where the oxidized cellulose fibers are in the middle and the CS-PEO electrospun mats are on the outer surfaces (Fig. 1).

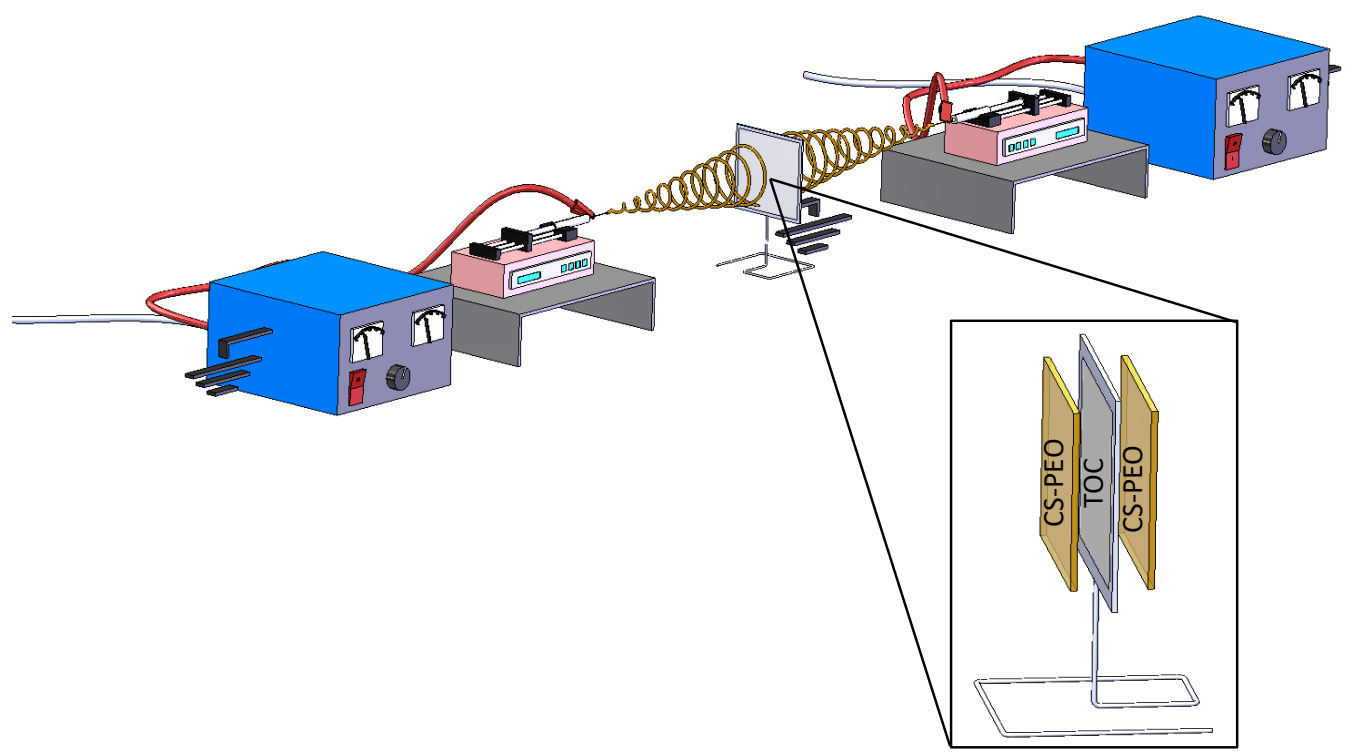

Fig. 1 Experimental set-up of electrospinning for the preparation of the CS-PEO/TOC bio-based composite 
The electrospinning conditions to obtain the CS-PEO nanofibers were described in a previous work (Cardenas Bates et al. 2020). Briefly, the polymers were firstly dissolved in their corresponding solvent; CS in acetic acid $90 \%$ and PEO in water. Subsequently, both solutions were mixed at a ratio of 4:3 by weight of CS:PEO and stirred continuously for $2 \mathrm{~h}$. Finally, the blended solutions were kept at rest at room temperature for $3 \mathrm{~h}$ before being electrospun over the TOC handsheet.

Different CS-PEO electrospinning time were tested (2,3 and $4 \mathrm{~h})$ in order to study the effect of the nanofiber coating weight on the physical and chemical properties of the bio-based composite. The samples are named as xCS-PEO/TOC, in which $\mathrm{x}(\mathrm{h})$ is the CS-PEO electrospinning time. Thus, three different bio-based composites having different grammages of CS-PEO layers were studied. A summary of the samples is listed in Table 2. A nanofibrous mat of single CS-PEO was also electrospun for $4 \mathrm{~h}$ and used as the control sample.

Table 2 CS-PEO/TOC mass ratio under different electrospinning time of CS-PEO

\begin{tabular}{|c|c|c|c|c|c|}
\hline Sample & $\begin{array}{c}\text { CS-PEO } \\
\text { electrospinning } \\
\text { time } \\
\text { (h) } \\
\end{array}$ & $\begin{array}{l}\text { CS-PEO:TOC } \\
\text { mass ratio }\end{array}$ & Thickness & Grammage & Density \\
\hline CS-PEO & 4 & N/A & $0.010 \pm 0.003$ & $3.27 \pm 0.19$ & $0.33 \pm 0.02$ \\
\hline TOC & N/A & N/A & $0.075 \pm 0.005$ & $61.6 \pm 0.9$ & $0.82 \pm 0.01$ \\
\hline 2CS-PEO/TOC & 2 & $9: 91 \pm 0.037$ & $0.088 \pm 0.003$ & $67.7 \pm 0.9$ & $0.77 \pm 0.01$ \\
\hline 3CS-PEO/TOC & 3 & $14: 86 \pm 0.005$ & $0.091 \pm 0.007$ & $71.6 \pm 0.9$ & $0.79 \pm 0.02$ \\
\hline 4CS-PEO/TOC & 4 & $18: 82 \pm 0.005$ & $0.102 \pm 0.002$ & $75.1 \pm 0.9$ & $0.74 \pm 0.02$ \\
\hline
\end{tabular}

Stabilization of CS-PEO/TOC nanofibrous mats

The CS-PEO/TOC bio-based composite should firstly be neutralized with an alkaline solution in order to convert the protonated amino groups $\left(\mathrm{NH}_{3}{ }^{+}\right)$to primary amine groups $\left(\mathrm{NH}_{2}\right)$. Otherwise, the CS-PEO nanofibers would not be stable in aqueous solutions due to the presence of high level of $\mathrm{NH}_{3}{ }^{+}$functional groups. However, cellulose naturally disperses in such an alkaline medium and this phenomenon is further increased for TOC due to the presence of the oxidized carboxyl groups $\left(\mathrm{COO}^{-}\right)$. To solve this problem, several $\mathrm{pH}$ values were investigated by adjustment of the concentration of a $\mathrm{NaHCO}_{3}$ solution in order to find the optimum one to maintain the aqueous stability of the material. Tests at $\mathrm{pH} \leq 6$ were performed using only distilled water as its $\mathrm{pH}$ is slightly acidic $(\sim 5.8)$. After neutralization treatment, the bio-based composite was rinsed several times with distilled water. Then, it was dried in vacuum oven overnight to remove any residual solvent.

\section{Characterization}

All characterizations were made for CS-PEO, TOC and xCS-PEO/TOC biocomposites samples and all measurements were repeated three times to guarantee good average results.

\section{Microscopy and Spectrometry}

The morphology of the fibers was observed by Scanning Electron Microscopy (SEM; SU1510 by HITACHI, Japan). The average fiber diameter was calculated using a software from SEM images (Abràmoff et al. 2004) based on 50 fibers per sample. The biocomposites were also analyzed by Fourier Transform Infrared (FTIR-ATR; Nicolet iS10, Thermo Scientific, USA) spectra for the identification of functional groups and specific bonds present in the material. The spectra were recorded between 4000 and $500 \mathrm{~cm}^{-1}$ by the diamond crystal method.

\section{Mechanical properties}

Mechanical properties of representative bio-based composites samples were determined using standard methods from the pulp and paper industry. Those methods were chosen because the main component of the bio-based composite material is a standard TOC fiber handsheet as described previously. The samples were preconditioned for $24 \mathrm{~h}$ at $50 \%$ relative humidity prior to measurements according to TAPPI Standard No. T $402 \mathrm{sp}-03$. The tensile strength measures the maximum tensile force developed in a test specimen before rupture. It was measured using a universal testing instrument; Instron 4201 with a $500 \mathrm{~N}$ load cell at a cross-head speed of $10 \mathrm{~mm} / \mathrm{min}$ according to TAPPI Standard No. T 494-om-01. However, due to the relatively small size of the electrospinning collector used, it was not possible 
to prepare samples of $50 \mathrm{~mm}$ in length as described in the standard method. Samples of $30 \mathrm{~mm}$ in length by $15 \mathrm{~mm}$ in width were used. The burst strength was also measured for each sample according to TAPPI Standard No. T 403-om02 . This test causes a specimen to deform into an approximately spherical shape until failure occurs by rupture. It was measured using a Mullen burst tester model C. In order to compare samples of sorbent media, tensile index and burst index were calculated by dividing tensile stress and burst strength by the handsheet grammage $\left(\mathrm{g} / \mathrm{m}^{2}\right)$. Both tests are thus related to the amount of material being loaded.

Pore size and water flux

Permeation tests were carried out using a dead-end stainless-steel cell (HP4750 from Sterlitech, USA) with an active membrane area of $14.6 \mathrm{~cm}^{2}$. In order to achieve steady water flux and ensure the pores are all open, the CS-PEO/TOC bio-based composites were precompacted with distilled water at $5 \mathrm{psi}$ for $10 \mathrm{~min}$ before testing. Then, all experiments were carried out at $7 \mathrm{psi}$ and room temperature, with $0.1 \mathrm{~L}$ of distilled water. The water flux was calculated using equation (1):

$J=\frac{V}{A \times t}$

Where $\mathrm{J}$ is the water flux $\left(\mathrm{L} / \mathrm{m}^{2} \mathrm{~h}\right), \mathrm{V}$ is the filtrate volume $(\mathrm{L}), \mathrm{A}$ is the area of the bio-based composite $\left(\mathrm{m}^{2}\right)$, and $\mathrm{t}$ is the filtration time (h).

The permeability of the bio-based composites was calculated from the water flux per unit membrane pressure. The pore size distribution was measured by the bubble point test defined by the American Society for Testing and Materials Standard Organization (ASTM F316-03 2019) also using the dead-end stainless-steel cell. Bio-based composites were soaked in distilled water for $30 \mathrm{~min}$ prior experiments. The gas pressure at the start of bubble forming was reported as bubble point. The Young-Laplace equation as follows was used to determine the diameter of the largest pores of the material:

$d=\frac{4 \gamma \cos \theta}{P}$

Where $\mathrm{P}$ is the bubble-point pressure (MPa), $\gamma$ the surface tension of the air-liquid interface $(\mathrm{N} / \mathrm{m}), \theta$ the liquid-solid contact angle when a gas bubble permeates a pore of the same radius, which means that the contact angle is $0^{\circ}$, and $\mathrm{d}$ the larger pore average diameter $(\mu \mathrm{m})$.

Batch adsorption of copper ions

Batch adsorption tests were made in order to determine the capacity of the material to capture copper ions in solutions. For this, $100 \mathrm{mg}$ of sorbent material were soaked into $50 \mathrm{~mL}$ of $\mathrm{CuSO}_{4} \cdot 5 \mathrm{H}_{2} \mathrm{O}$ aqueous solution at $100 \mathrm{ppm}$ copper concentration. Each test was carried out at $200 \mathrm{rpm}$ shaking speed, $\mathrm{pH} 6$ and room temperature. At every 30 min, the concentration of copper solution was determined by titration with EDTA until the copper concentration reached an equilibrium. The maximum adsorption capacity of the bio-based composite $\left(\mathrm{q}_{\mathrm{e}}\right)$ was calculated based on equation (3):

$q_{e}=\frac{C_{0}-C_{e}}{m} \times V$

Where $\mathrm{C}_{0}$ and $\mathrm{C}_{\mathrm{e}}$ are the initial and equilibrium copper concentration (ppm), respectively, $\mathrm{V}$ is the volume of copper solution (L), and $\mathrm{m}$ is the mass of the sorbent material (mg).

For the kinetic studies, non-linear pseudo-first order (4) and pseudo-second order models (5) were evaluated to elucidate the adsorption mechanism involved in the adsorption process.

$q_{t}=q_{e}\left(1-\exp ^{-k_{1} t}\right)$

$q_{t}=\frac{k_{2} q_{e}^{2} t}{1+k_{2} q_{e} t}$

Where $\mathrm{k}_{1}\left(\mathrm{~min}^{-1}\right)$ and $\mathrm{k}_{2}(\mathrm{~g} /(\mathrm{g} \mathrm{min}))$ are the pseudo first order and pseudo second order adsorption rate constants, respectively, and $\mathrm{q}_{\mathrm{t}}$ is the amount of copper adsorbed $(\mathrm{mg} / \mathrm{g})$ at time $\mathrm{t}(\mathrm{min})$. 


\section{Results and discussion}

Morphology study of sorbent materials

CS-PEO, TOC and CS-PEO/TOC bio-based composites samples were carefully prepared under the given conditions. They were examined by SEM to study their structure and morphology. Figures $2 \mathrm{a}, 2 \mathrm{~b}$ and $2 \mathrm{c}$ present the CS-PEO, TOC and 3CS-PEO/TOC samples, respectively. All materials exhibit a well-defined network structure with uniform and continuous fibers. The CS-PEO nanofibrous mat shows bead-free nanofibers with average diameters of $159.3 \pm$ $33.7 \mathrm{~nm}$. The TOC handsheet presents an average diameter of $21.7 \pm 5.1 \mu \mathrm{m}$.
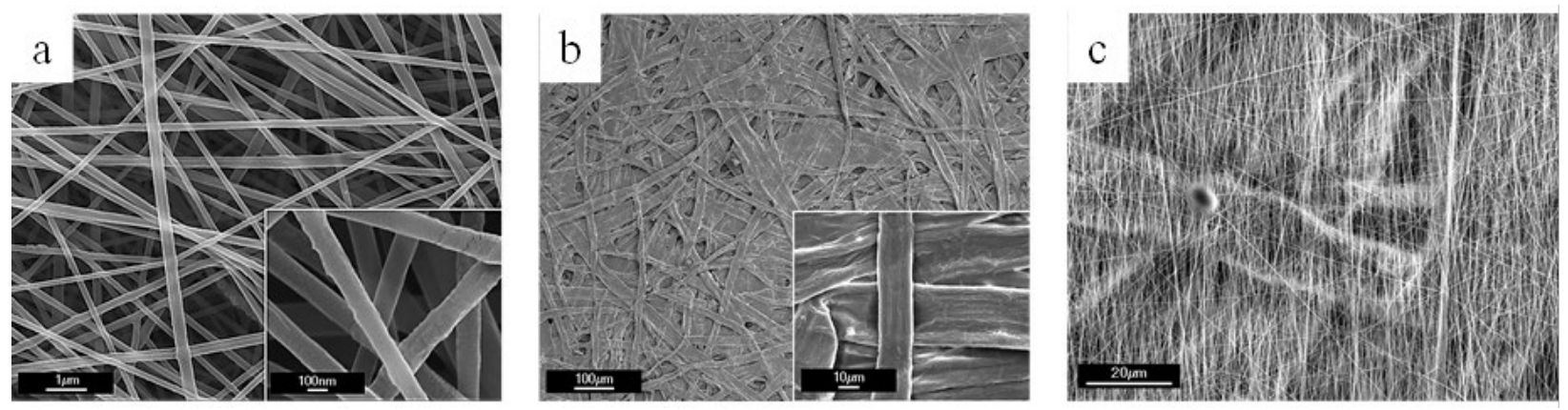

Fig. 2 SEM micrographs showing morphology of the fibrous materials; (a) CS-PEO, (b) TOC, (c) 3CS-PEO/TOC bio-based composite (surface)

In the case of the CS-PEO/TOC bio-based composite, the SEM micrographs were taken from surface and cross-section (Figs. 2c and 3). As shown in Fig. 3, the CS-PEO nanofibers coating on the TOC were highly homogeneous. Both CS-PEO and TOC mats kept their fiber structure when assembled with minimal morphological defects such as the presence of very few micro-beads. It can also be seen that a thin CS-PEO electrospun nanofibers mat (Fig 2c) is entirely recovering the cellulose fibers (TOC pores), which is believe to decrease the porosity of the CS-PEO/TOC bio-based composite when compared to TOC mat alone. This will be confirmed later in the pore size and water flux section. A similar phenomenon was observed by Goetz et al. 2016 who made electrospun cellulose acetate membranes coated with chitin nanocrystals. Fig. 3a shows the "sandwich-like" structure of the bio-based composite. In Fig. 3b, the three layers (CS-PEO/TOC/CS-PEO in that order) can be easily seen, especially in Fig. 3c where the thin layer of CS-PEO electrospun nanofibers is clearly visible on the surface of the TOC.
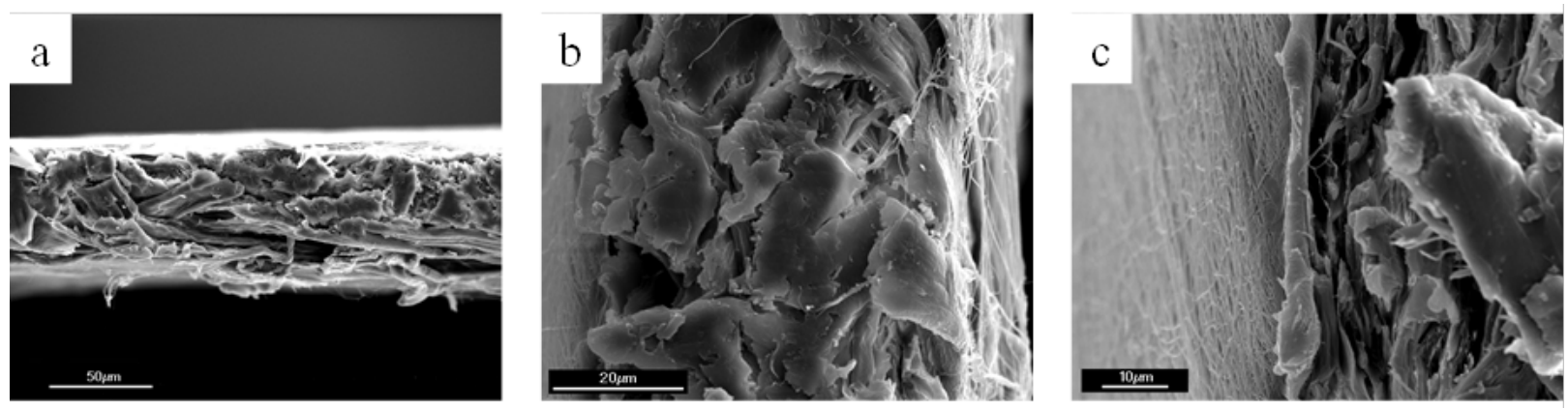

Fig. 3 Morphology of the 3CS-PEO/TOC bio-based composite (cross section); (a) horizontal view, (b) vertical view of the three layers, $(\mathbf{c})$ vertical view with zoom on one side of the material

Stabilisation of CS-PEO/TOC bio-based composite in aqueous solutions

A neutralization of the chitosan's amino groups $\left(\mathrm{NH}_{3}{ }^{+}\right.$to $\left.\mathrm{NH}_{2}\right)$ is needed for the CS-PEO layers in order to prevent its dissolution in aqueous medium. These $\mathrm{NH}_{2}$ groups are also required to attract copper ions by a chelation mechanism (Mekahlia and Bouzid 2009; Abdullah et al. 2019). Considering that the pKa of chitosan is 6.5 (Phan et al. 2018; Zhang et al. 2018), a pH of around 8.5 is required to provide a complete neutralization. However, at an alkaline $\mathrm{pH}$, the TEMPO cellulosic fibers ( $\mathrm{pKa} \sim 4$ ) (Spaic et al. 2014) is redispersed in water due to the repulsion between the carboxylate $\left(\mathrm{COO}^{-}\right)$groups. Fig. 4 shows the behavior of the bio-based composite at different $\mathrm{pH}$. The $\mathrm{pH}$ adjustment was done with a sodium bicarbonate solution. Results show that the structure of the material is maintained at $\mathrm{pH} 8$. 
This is due to electrostatic interactions between polysaccharides (Soni et al. 2016; Mao et al. 2019). On the other hand, at a $\mathrm{pH}$ higher than 8 , repulsion between the $\mathrm{COO}^{-}$groups of the TOC is important causing a destruction of the fiber network of the TOC handsheet and redispersion of the cellulose fibers in the aqueous solution. Therefore, only the CS-PEO layers are still unaffected and can be recovered. For $\mathrm{pH}$ lower than 8 , the more acidic the solution was, the higher the loss of mass of the CS-PEO layers was observed because of the chitosan dissolution. Thus, only the TOC handsheet can be recovered. Therefore, $\mathrm{pH} 8$ was selected as optimal, since it provides conditions to maintain the structural integrity of the composite media as well as a high conversion of $\mathrm{NH}_{3}{ }^{+}$groups to $\mathrm{NH}_{2}$ in the chitosan.

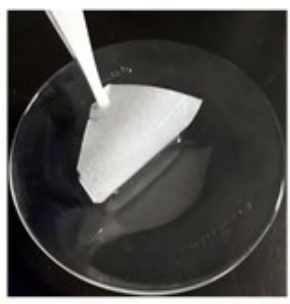

$\mathrm{pH} \leq 6$

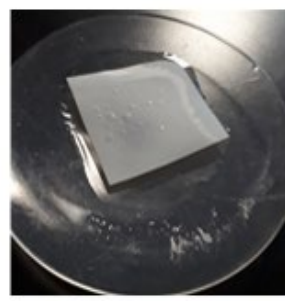

$\mathrm{pH}=7$

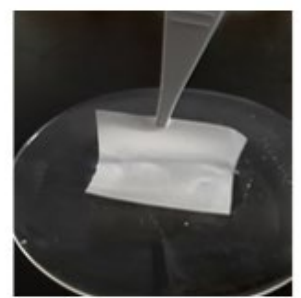

$\mathrm{pH}=8$

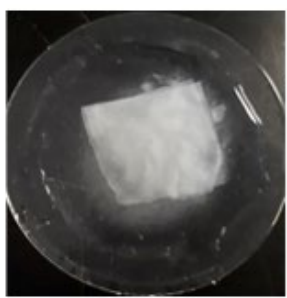

$\mathrm{pH}=9$

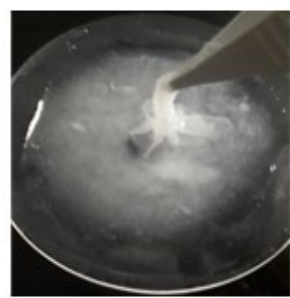

$\mathrm{pH} \geq 10$

Fig. 4 Photograph of the CS-PEO/TOC bio-based composite at different $\mathrm{pH}$ values

However, even if the visual structure of the material after the stabilisation was maintained, SEM micrographs in Fig. 5 demonstrate that its initial fibrous microstructure has changed. CS-PEO nanofibers exhibit a different arrangement. Fig. 5b shows that they stick not only to each other, but mainly to the TOC fibers. This welding at the cross points is thought to cause a decrease in the available active sites of the fibers but a strengthening effect between TOC and CSPEO layers, and thus a resistance to delamination. The mechanical enhancing effect due to the bonding points between the fibers has been previously reported by Li et al. 2017. This assumption will be further confirmed in the mechanical properties section.

This change in structure is believed to be due to the dissolution of both PEO during rinsing with water after the neutralization treatment and to the $\mathrm{NH}_{3}{ }^{+} \mathrm{CH}_{3} \mathrm{COO}^{-}$salt which is formed during the dissolution of chitosan in acetic acid. This behavior has also been observed by other authors (Salihu et al. 2012; Phan et al. 2018). The first author explains that in an heterogeneous blend, one of the components would dissolve on its own leaving the other component in the form of porous or hollow fibers. However, in a homogeneous blend, the attempt to dissolve one of the components causes the breakdown of the total structure. This is consistent with the EDX results of CS-PEO nanofibers reported in our previous publication (Cardenas Bates et al. 2020) where an homogeneous dispersion of all elements was observed, confirming the homogeneity of the components in the fibers.
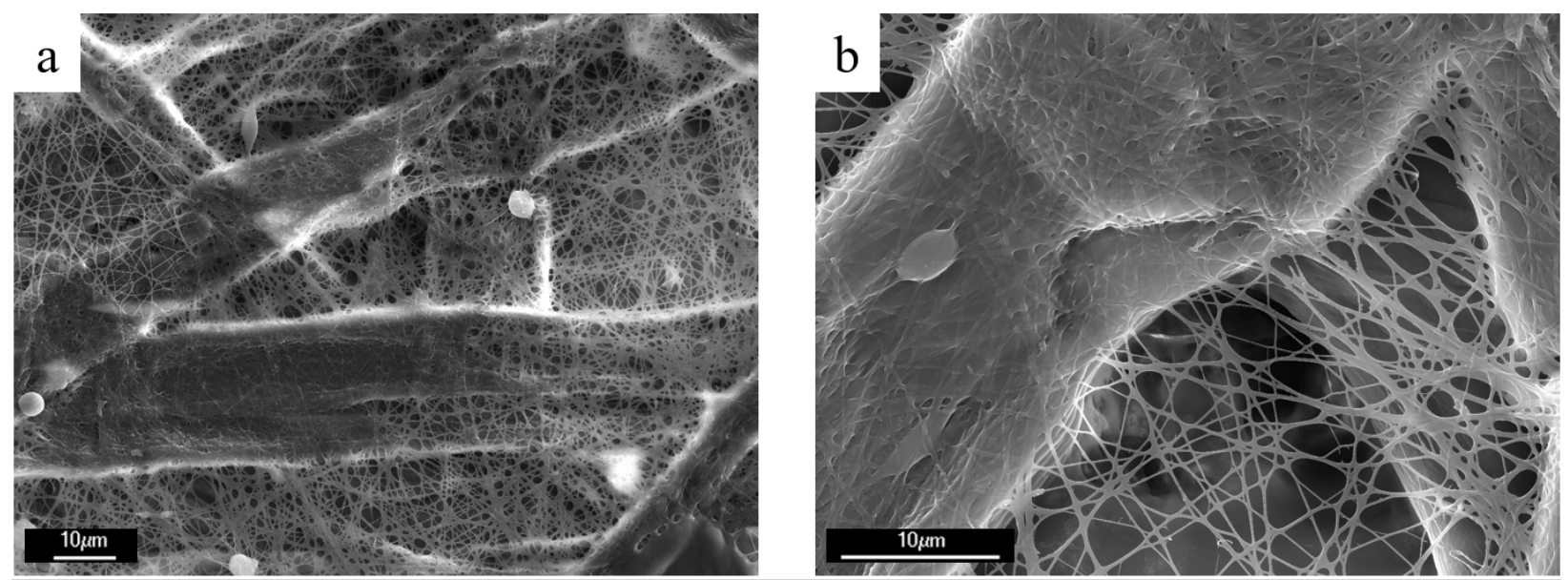

Fig. 5 Morphology of the 3CS-PEO/TOC bio-based composite after neutralization treatment with $\mathrm{NaHCO}_{3}$ at (a) $\mathrm{x} 1500$ and (b) x 2500 magnifications

Molecular analysis by FTIR Spectroscopy

The spectra of CS-PEO nanofibrous mat, TOC handsheet and the CS-PEO/TOC bio-based composite were assessed by FTIR-ATR spectroscopy (Fig. 6). 

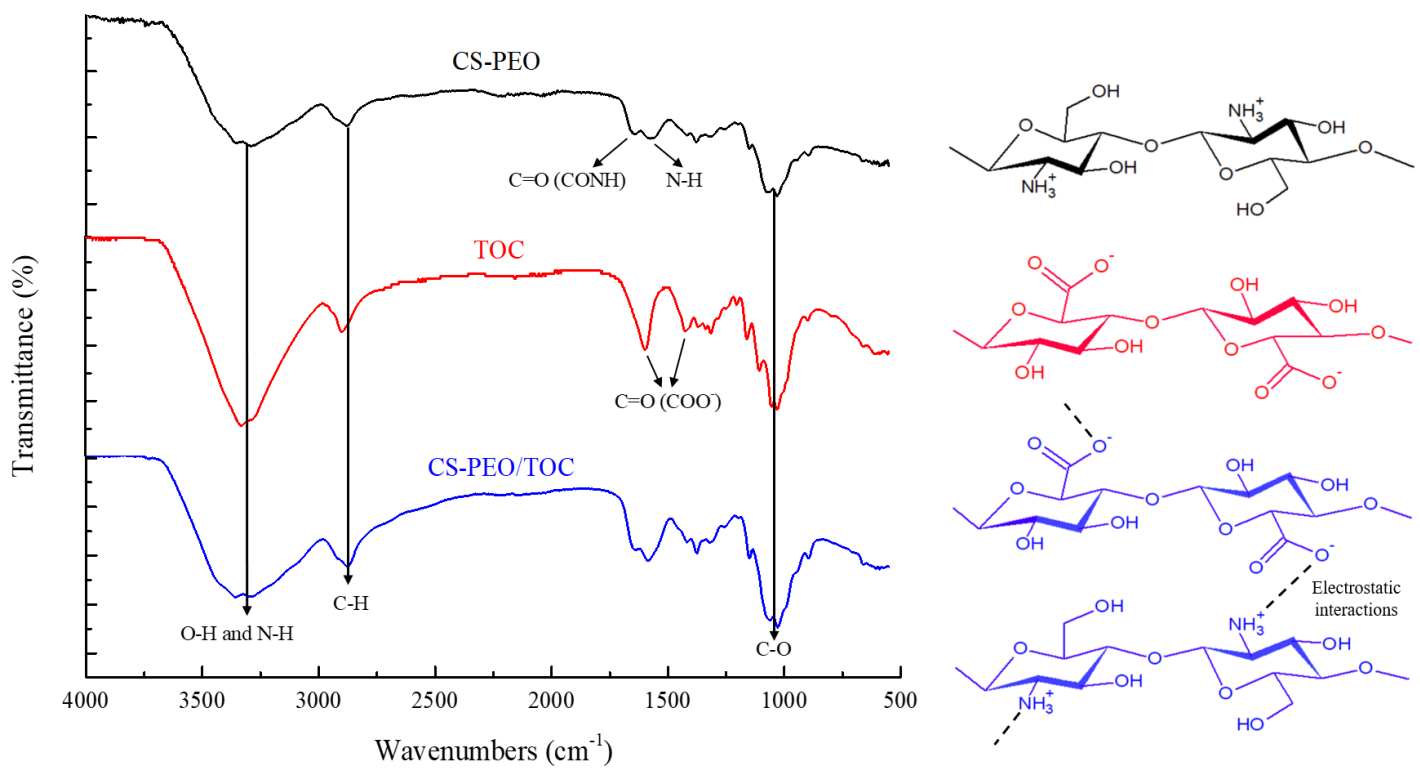

Fig. 6 FTIR Spectra of a CS-PEO b TOC c CS-PEO/TOC bio-based composite

The spectra of CS-PEO displays characteristic absorption bands at 1576 and $1654 \mathrm{~cm}^{-1}$. The first band corresponds to the $\mathrm{N}-\mathrm{H}$ bending vibrations (Aliabadi et al. 2013; Ridolfi et al. 2017) and the second band corresponds to the $\mathrm{C}=\mathrm{O}$ stretching of the acetyl group from chitin, since, as we have previously mentioned, chitosan is $75-85 \%$ deacetylated, so a few acetyl groups are still present (Ridolfi et al. 2017; Phan et al. 2018). The bands located at 1028 and $1075 \mathrm{~cm}^{-}$ ${ }^{1}$ correspond to the C-O-C stretching vibrations (Aliabadi et al. 2013; Ridolfi et al. 2017). The absorption band at 2880 $\mathrm{cm}^{-1}$ and the broad band between 3600 and $3100 \mathrm{~cm}^{-1}$ in all spectrum, are attributed to the stretching vibration peak of alkane $\mathrm{C}-\mathrm{H}$ and, to $\mathrm{N}-\mathrm{H}$ present in chitosan and $\mathrm{O}-\mathrm{H}$ stretching present in all polymers, respectively. The spectra of TOC handsheet shows characteristic peaks of the TEMPO-oxidized fibers corresponding to the carbonyl stretching vibration at $1597 \mathrm{~cm}^{-1}\left(v_{\mathrm{as}} \mathrm{COO}^{-}\right)$and $1424 \mathrm{~cm}^{-1}\left(v_{\mathrm{s}} \mathrm{COO}^{-}\right)$(Jin et al. 2014; Sehaqui et al. 2014; Onyianta et al. 2017). Concerning the CS-PEO/TOC bio-based composite, the analysis of the FTIR spectra confirms that the polymers are all present since their characteristic's bands are detected. Also, no new peaks appeared, which means that there is no formation of covalent bonds (e.g., amide bonds) but rather electrostatic interactions. Likewise, there is no evidence of broadering or shifting in the peak position, indicating that no hydrogen bonds are present between CS-PEO and TOC. The values of the absorption bands in all samples were taken from (Sigma Aldrich 2020). They are all in agreement with the literature data presented in similar works (Salihu et al. 2012; Aliabadi et al. 2013; Jin et al. 2014; Sehaqui et al. 2014; Soni et al. 2016; Onyianta et al. 2017; Ridolfi et al. 2017; Phan et al. 2018; Wang et al. 2018; Mao et al. 2019).

\section{Mechanical properties of sorbent materials}

To provide a suitable bio-based composite sorbent media for industrial wastewater treatment applications, it is not only necessary to develop a material with specific adsorption capacities, but also to develop a robust material capable of withstanding high-pressure drops during filtration of liquid. It is well known that electrospun nonwoven mats can be tailor-made to provide specific adsorption sites for target contaminants, but their mechanical strength are weak. In this study, it is proposed to improve the mechanical properties of CS-PEO electrospun nonwoven mats by addition of a cellulosic fiber (TOC) handsheet as a reinforcing structure porous core, on which thin chitosan nanofibers mat layers are electrospun on both sides. Fig. 7 shows representative stress-strain curves of CS-PEO nanofiber mat, TOC, and bio-based composite samples at various electrospinning time. Table 3 also presents elongation at break (strain), Young's modulus, tensile strength and load at break data from Fig. 7. Stress-strain curves show a typical elastic and plastic nature of the material. Each sample presents an initial flat behavior before tensile stress start to be recorded. This could be attributed to several phenomena including, a slight uncontrolled sample slipping in the jaws at the start of stretch, but also nanofiber straightening out or realignment under uniaxial stretching load application (Szczesny et al. 2017). The latter seems to be more important as the quantity of nanofibers increases with electrospinning time. This behavior is consistent with other works (Li et al. 2015, 2019; Phan et al. 2018; Szymańska-Chargot et al. 2019). Obviously, the CS-PEO electrospun mat has low tensile strength properties compared to TOC (11.86 MPa vs 46.69 $\mathrm{MPa}$ ). The Young's modulus is approximately 4 times higher for TOC. CS-PEO mat is clearly a weaker material 
compared to the TOC handsheet. This could be mostly attributed to the lower amount of material (lower grammage), the porous structure of the non-woven mat, and possibly poor nanofiber bonding especially at the joint (Zhou et al. 2011; Li et al. 2017). On the contrary, TOC handsheet shows higher tensile strength but lower potential for elastic deformation. Biocomposite samples combining TOC and electrospun nanofibers show intermediate patterns ranging between TOC and CS-PEO materials. A synergetic effect is clearly observed as both tensile strength and elongation at break are increased, when compared with CS-PEO mat. However, the increase of CS-PEO electrospinning time over the TOC has rather an adverse impact on the breaking tensile stress, Young's modulus, and elongation at break (see Table 3). Addition of electrospun nanofibers follows an inverse relationship relative to electrospinning time. This tendency has also been reported in other publications (Liu and Bai 2005; Goetz et al. 2016; Weng et al. 2017; Yang et al. 2018). This is likely because after approximately $2 \mathrm{~h}$ of electrospinning, the electrospun chitosan nanofibers that continue to be deposited over the TOC handsheet are no longer in contact with the cellulose fibers, but rather, are in contact with the previously deposited chitosan nanofibers. Therefore, at this point, there are more chitosan intramolecular interactions than intermolecular interactions with cellulose. According to (Yang et al. 2018), this leads to a non-homogeneous interaction in the bio-based composite resulting with weaker interfacial and poorer elastic strength properties.

To study the effect of TOC handsheet reinforcement of the bio-based composite media, specific strength properties were analyzed. Table 3 also presents tensile and burst indexes to allow direct comparison of samples irrespective of the amount of material in the sample. The tensile strength is the breaking force per cross-section area with units of MPa. In the paper industry, it is usually expressed as force per specimen width in $\mathrm{kN} / \mathrm{m}$. The tensile index in $\mathrm{N} \bullet \mathrm{m} / \mathrm{g}$ is obtained by dividing the strength per width by the grammage $\left(\mathrm{g} / \mathrm{m}^{2}\right)$. The burst index is the burst value in $\mathrm{kPa}$ measured with the instrument divided by the grammage. Both values are thus normalized to the grammage of the sample. The tensile index calculated for each sample follows the trend presented previously and confirms that electrospinning of nanofibers on the TOC handsheet improves the strength properties of a nanofiber web and creates a bio-based composite structure for water treatment applications. However, lower properties are developed with electrospinning time. On the other hand, the tensile index seems to be less sensitive especially at low electrospinning time with values closed to those achieved for TOC sample $(51.58$ vs $60.60 \mathrm{~N} \cdot \mathrm{m} / \mathrm{g})$. Analysis of burst index values are much more difficult to interpret. All values, except the one for the CS-PEO mat, are in the same range (see Table 3). It is thus difficult to draw conclusions based only on burst index. However, it is clear that electrospinning CS-PEO nanofibers on both sides of a TOC handsheet improves significantly the burst index relative to the nanofiber mat alone (see Table 3). This behavior was already expected as some scientific papers have demonstrated that incorporation of cellulose into a chitosan matrix improve the mechanical strength (Liu and Bai 2005; El Miri et al. 2015; H.P.S et al. 2016; Soni et al. 2016; Jalvo et al. 2017; Yadav et al. 2020). This enhancement is attributed to the excellent mechanical properties of cellulose and the interactions between CS-PEO and TOC making polymer chains more stable and rigid than CS-PEO alone (Zhou et al. 2011; Phan et al. 2018).

Based on the results presented, the 2CS-PEO/TOC bio-based composite exhibited the best mechanical properties and therefore, the one to be optimized from now on. The tensile strength and strain values of this bio-based composite were compared to previous related studies listed in Table 5. From this table it can be observed that 2CS-PEO/TOC composite presents good mechanical properties, both in ultimate elongation and tensile strength, when compared with the other composites. Some authors obtained higher tensile strength values. However the ultimate elongation values were considerably lower (Karim et al. 2014; Weng et al. 2017).

Overall, the bio-based composite sorbent provides improved mechanical strength as shown by tensile index and burst index. Although lower ultimate strength at break have been achieved, higher elongation capability are developed especially for low electrospinning time. This is an indication that a softer or more ductile material is developed. A compromise between ultimate resistance and elongation should be find to make a robust adsorbent. However, this material must also take into account other constraints such as the permeability to liquid and the adsorption capacity of the material. 


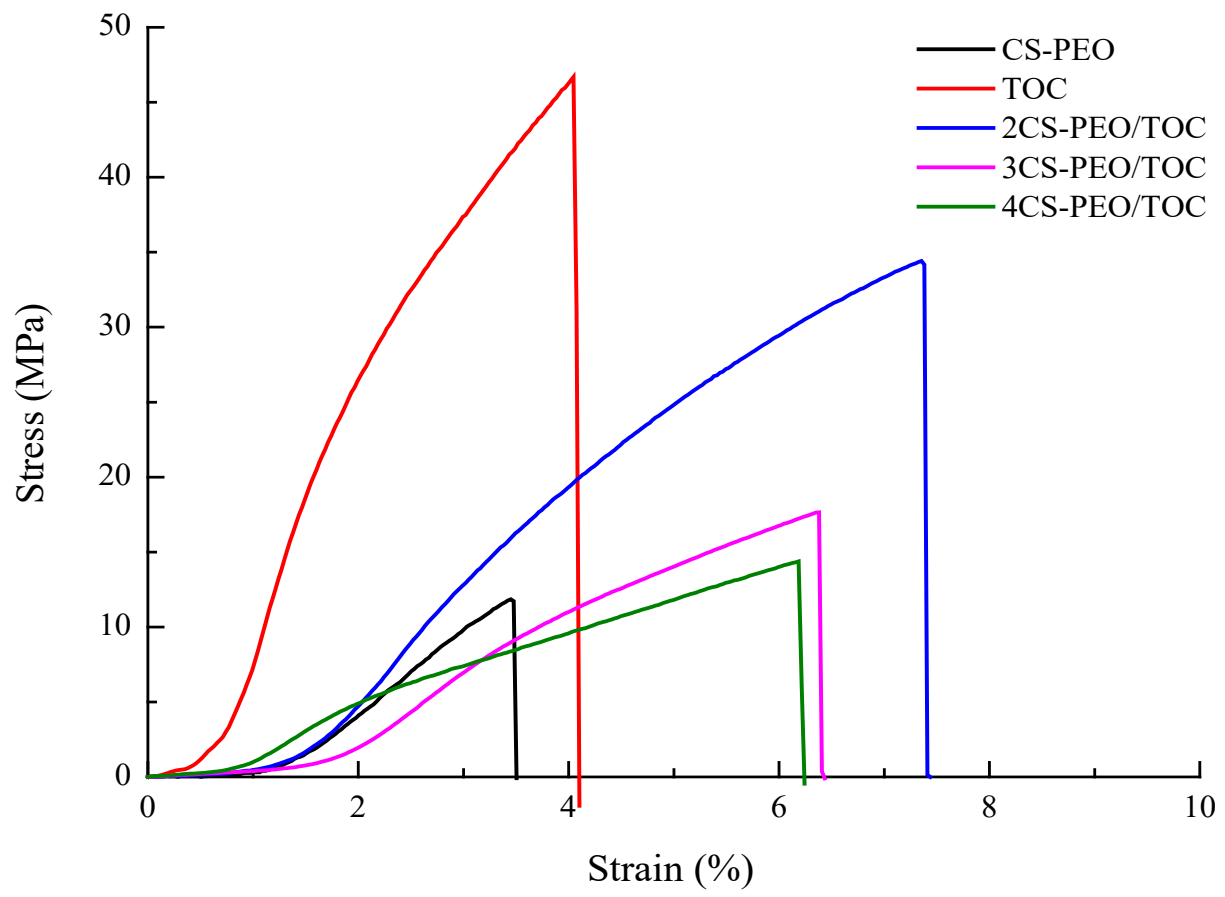

Fig. 7 Stress-Strain curves for CS-PEO, TOC and xCS-PEO/TOC

Table 3 Effect of TOC on mechanical properties of the biocomposites

\begin{tabular}{lcccccc}
\hline \multicolumn{1}{c}{ Material } & Strain & $\begin{array}{c}\text { Young's } \\
\text { modulus } \\
(\mathbf{M P a})\end{array}$ & $\begin{array}{c}\text { Tensile } \\
\text { strength } \\
\mathbf{( M P a )}\end{array}$ & $\begin{array}{c}\text { Load at } \\
\text { break } \\
\mathbf{( N )}\end{array}$ & $\begin{array}{c}\text { Tensile } \\
\text { index } \\
(\mathbf{N} \bullet \mathbf{m} / \mathbf{g})\end{array}$ & Burst index \\
$\mathbf{( \% )}$ & $\mathbf{( k P a \cdot \mathbf { m } ^ { 2 } / \mathbf { g } )}$ \\
\hline CS-PEO & 3.15 & 595.36 & 11.86 & 1.30 & $26.50 \pm 2.60$ & $<0.30$ \\
TOC & 4.10 & 2370.09 & 46.69 & 56.03 & $60.60 \pm 1.95$ & $1.34 \pm 0.18$ \\
2CS-PEO/TOC & 7.94 & 841.54 & 34.42 & 52.40 & $51.58 \pm 4.01$ & $1.40 \pm 0.23$ \\
3CS-PEO/TOC & 6.41 & 534.75 & 17.65 & 34.42 & $32.01 \pm 1.75$ & $1.52 \pm 0.01$ \\
4CS-PEO/TOC & 6.24 & 377.33 & 14.38 & 30.19 & $26.78 \pm 7.36$ & $1.68 \pm 0.02$ \\
\hline
\end{tabular}

Pore size and water flux

Table 4 clearly shows that the water flux decreases when CS-PEO is electrospun on the bio-based composite. This is attributed to two reasons: First, as mentioned previously, Fig. 3 displays that CS-PEO nanofibers are deposited homogeneously over a TOC handsheet, thus, partly plugging the pores of the cellulose fibers. Second, the pore size in CS-PEO nanofiber mats $(3.22 \mu \mathrm{m})$ is smaller than the pore size in the TOC handsheets $(6.59 \mu \mathrm{m})$. Those effects could explain the reduction in water flux. A reduction in water flux is also observed when the CS-PEO electrospinning time is increased from $140.02 \mathrm{Lm}^{-2} \mathrm{~h}^{-1}$ for 2CS-PEO/TOC to $0.35 \mathrm{Lm}^{-2} \mathrm{~h}^{-1}$ for $4 \mathrm{CS}-\mathrm{PEO} / \mathrm{TOC}$. This is because there is more nanofibers recovering the TOC handsheet and thus higher opportunity for pore plugging. This means that the CS-PEO layers are the dominant factor controlling the porosity of the material. In our case, the 2CS-PEO/TOC material provided the most permeable material and once again, the one to be optimized from now on. As mentioned previously, a compromise regarding electrospinning time must be made to develop a suitable bio-based composite for this particular application.

Table 4. Pore size and water permeability of all biocomposites

\begin{tabular}{lccc}
\hline \multicolumn{1}{c}{ Material } & \multicolumn{2}{c}{ Pore size $(\boldsymbol{\mu m})$} & Water Flux \\
& Largest pore & Mean pore & $\left(\mathbf{L ~ m}^{-2} \mathbf{h}^{-\mathbf{1}}\right)$ \\
\hline CS-PEO & $3.97 \pm 0.54$ & $3.22 \pm 0.17$ & $98.1 \pm 9.3$ \\
TOC & $8.75 \pm 0.21$ & $6.59 \pm 0.10$ & $1404 \pm 426$ \\
2CS-PEO/TOC & $3.96 \pm 0.14$ & $2.82 \pm 0.34$ & $140 \pm 17$ \\
3CS-PEO/TOC & $2.77 \pm 0.28$ & $1.64 \pm 0.22$ & $3.7 \pm 0.4$ \\
4CS-PEO/TOC & $1.85 \pm 0.08$ & $0.96 \pm 0.03$ & $0.35 \pm 0.01$ \\
\hline
\end{tabular}


Since $2 \mathrm{CS}-\mathrm{PEO} / \mathrm{TOC}$ is the one presenting the best porosity and permeability characteristics, it's average pore size and water flux values have been compared to previous related studies (Table 5).

From the highlighted works in Table 1 (Electrospun cellulose/chitosan composites for wastewater treatment), only Brandes et al. 2020 evaluated the water flux of their composite. However, they did not reported the average pore size. Therefore, in order to compare our values with other similar works, chitosan/cellulose based composites produced from other techniques but also for water treatment applications have also been reported in Table 5.

It can be seen that 2CS-PEO/TOC sandwich-like new concept have significantly higher water flux compared to the previous reported cellulose/chitosan composites. However, it is still les permeable than composites made from other different matrix (Ma et al. 2012; Goetz et al. 2016; Jabur et al. 2016; Jalvo et al. 2017). The bio-based composite also reveals a macroporous structure (pore size $>50 \mathrm{~nm}$ ), which is very useful in water treatment adsorbents, and rarely achieved by the electrospinning technique.

Table 5. Permeability and mechanical properties of various cellulose/chitosan composites

\begin{tabular}{|c|c|c|c|c|c|}
\hline Matrix polymers & $\begin{array}{c}\text { Water flux } \\
\left(\mathrm{L} / \mathrm{m}^{2} \mathbf{h M P a}\right)\end{array}$ & $\begin{array}{c}\text { Average } \\
\text { pore size } \\
(\mathrm{nm})\end{array}$ & Strain (\%) & $\begin{array}{c}\text { Tensile } \\
\text { strength } \\
\text { (MPa) }\end{array}$ & Reference \\
\hline $\begin{array}{c}\text { Cellulose } \\
\text { acetate/Chitosan }\end{array}$ & 92.2 & 72 & 27.97 & 26.16 & $\begin{array}{l}\text { (Liu and Bai } \\
\text { 2005) }\end{array}$ \\
\hline $\begin{array}{l}\text { Cellulose acetate/ N,O- } \\
\text { Carboxymethyl chitosan }\end{array}$ & 160 & Unlisted & 23.45 & 7.4 & $\begin{array}{l}\text { (Boricha } \\
\text { and Murthy } \\
\text { 2010) }\end{array}$ \\
\hline $\begin{array}{c}\text { Cellulose } \\
\text { nanocrystals/Entities } \\
\text { chitosan }\end{array}$ & 64 & $10-13$ & $0.23 \pm 0.5$ & $\begin{array}{c}318 \pm \\
0.4\end{array}$ & $\begin{array}{l}\text { (Karim et al. } \\
\text { 2014) }\end{array}$ \\
\hline $\begin{array}{l}\text { Cellulose acetate/ Poly } \\
\text { (ethylene glycol)/ } \\
\text { Chitosan }\end{array}$ & 0.77 & Unlisted & Unlisted & Unlisted & $\begin{array}{l}\text { (Waheed et } \\
\text { al. 2014) }\end{array}$ \\
\hline Cellulose/Chitosan & 8.63 & 0.78 & Unlisted & Unlisted & $\begin{array}{c}\text { (Ghaee et al. } \\
\text { 2016) }\end{array}$ \\
\hline Cellulose/ Chitosan & 27.52 & $<1 \mathrm{~nm}$ & Unlisted & $\sim 50$ & $\begin{array}{l}\text { (Weng et al. } \\
\text { 2017) }\end{array}$ \\
\hline Cellulose/ Chitosan & 2 & $<200$ & Unlisted & Unlisted & $\begin{array}{l}\text { (Istirokhatun } \\
\text { et al. 2017) }\end{array}$ \\
\hline $\begin{array}{l}\text { Cellulose acetate/ } \\
\text { Chitosan }\end{array}$ & Unlisted & Unlisted & 5.5 & 17 & $\begin{array}{l}\text { (Phan et al. } \\
\text { 2018) }\end{array}$ \\
\hline $\begin{array}{c}\text { Cellulose nanocrystals/ } \\
\text { Chitosan/Polyvinyl } \\
\text { alcohol }\end{array}$ & Unlisted & Unlisted & 25 & Unlisted & $\begin{array}{c}\text { (Wang et al. } \\
\text { 2018) }\end{array}$ \\
\hline $\begin{array}{c}\text { Cellulose } \\
\text { acetate/Chitosan }\end{array}$ & Unlisted & Unlisted & $0.14167 \mathrm{~mm} / \mathrm{mm}$ & 0.01515 & $\begin{array}{l}\text { (Aquino et } \\
\text { al. 2018) }\end{array}$ \\
\hline $\begin{array}{l}\text { Phosphorylated } \\
\text { cellulose/Chitosan }\end{array}$ & 109.6 & Unlisted & 4.54 & 21.49 & $\begin{array}{l}\text { (Brandes et } \\
\text { al. 2020) }\end{array}$ \\
\hline $\begin{array}{c}\text { Bamboo cellulose/ } \\
\text { Chitosan }\end{array}$ & 31.2 & $0.7 \mathrm{~nm}$ & Unlisted & Unlisted & $\begin{array}{l}\text { (Weng et al. } \\
2020 \text { ) }\end{array}$ \\
\hline $\begin{array}{c}\text { TEMPO-Oxidized } \\
\text { cellulose/ Poly (ethylene } \\
\text { oxixde)/ Chitosan }\end{array}$ & $2,900.75$ & $2.82 \mu \mathrm{m}$ & 7.94 & 34.42 & $\begin{array}{l}\text { Present } \\
\text { study }\end{array}$ \\
\hline
\end{tabular}

Copper ions adsorption

The adsorption tests were studied using batch experiments at an initial copper ion concentration of $100 \mathrm{mg} / \mathrm{L}$. The adsorption capacity of all biocomposites samples and the effect of contact time are illustrated in Table 6 and Fig. 8, respectively. Copper ions adsorption rose rapidly during the first $15 \mathrm{~min}$, and then slowly stabilized. This initial rise in copper adsorption is attributed to the large presence of active sites that are available on the surface of the material. It is also be shown that although oxidized cellulose fibers are able of adsorbing copper ions (17.8\%), CS-PEO 
nanofibers have a much higher adsorption capacity (91.5\%). Therefore, it can be inferred that the higher the amount of CS-PEO, the higher the adsorption of copper ions. However, the xCS-PEO/TOC curves show that despite increasing the amount of chitosan, the adsorption capacity does not increase significantly. This behavior occurs because 3 and 4 $\mathrm{h}$ of electrospinning on each side of the TOC handsheet seals the core media resulting with a lower permeability to liquid. Therefore, the fast and easy accessibility of copper ions to active sites are strongly reduced. Composite 2CS$\mathrm{PEO} / \mathrm{TOC}$, while being the best compromise for water permeability and mechanical properties, does not clearly stand out from the others CS-PEO/TOC composites copper adsorption. Still, CS-PEO/TOC composites are better than TOC alone but are way less effective than CS-PEO. The maximum adsorption capacity of this composite was compared to data from the literature obtained with different adsorbents (Table 8). Results show that the 4CS-PEO/TOC bio-based composite has lower adsorption capacity towards copper ions than most of the compared adsorbents. Clearly, optimization of the adsorption capacity is required. Therefore, further studies will be carried out on this issue.

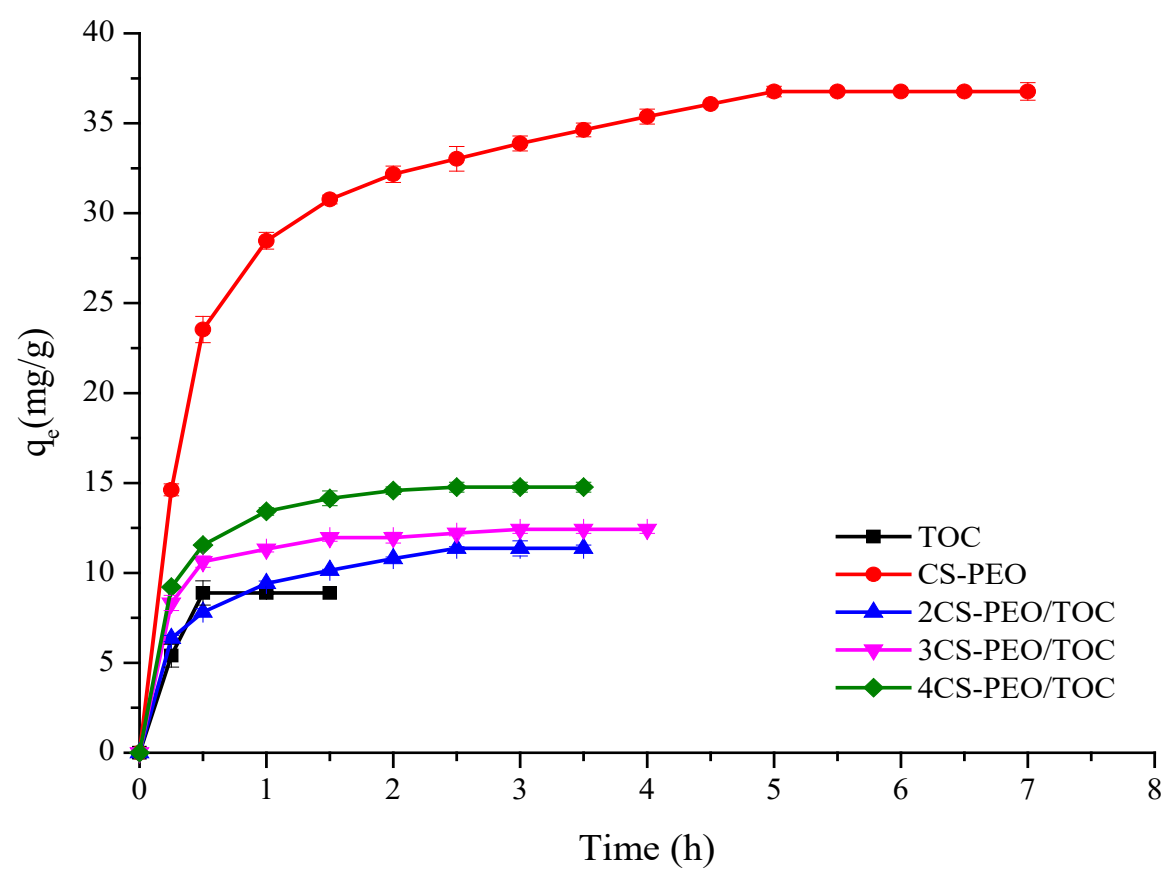

Fig. 8 Effect of contact time on the adsorption of copper ions onto the five different biocomposites

Table 6. Comparison of copper adsorption capacity for all type of material

\begin{tabular}{lcc}
\hline \multicolumn{1}{c}{ Material } & $\begin{array}{c}\text { Copper adsorption capacity } \\
(\mathbf{\% )}\end{array}$ & $\begin{array}{c}\text { Copper uptake per gram of } \\
\text { total material } \\
(\mathbf{m g} / \mathbf{g}))\end{array}$ \\
\hline TOC & 17.76 & 8.32 \\
CS-PEO & 91.45 & 36.76 \\
2CS-PEO/TOC & 23.53 & 11.36 \\
3CS-PEO/TOC & 27.12 & 12.42 \\
4CS-PEO/TOC & 29.24 & 14.76 \\
\hline
\end{tabular}

In order to analyze the nature of the mechanism involved during the adsorption process as well as the role of the material's surface, two adsorption kinetic models were evaluated: Pseudo-first order (PFO) and Pseudo-second order (PSO). The parameters for both non-linear models were obtained using Matlab software, and results are presented in Fig. 9 and Table 7. Both models present high $\mathrm{R}^{2}$ values, showing that they are both involved in the rate of adsorption. This indicates that a chemical and physical adsorption coexists during the interaction between the copper ions and the xCS-PEO/TOC. However, Root mean square error (RMSE) values are smaller in the pseudo-second order model than in the pseudo-first order model. This indicates that pseudo-second order model best fitted to the data. Besides, it is reported (Gerente et al. 2007; Lakhdhar et al. 2016) that the plots of the first-order equation are only applicable in the first 30 min of interaction and not for the whole range of contact time. Therefore, it is considered that the adsorption is mostly chemical. A similar behavior was observed by Phan et al. 2018 and Wang et al. 2018 who also obtained high $\mathrm{R}^{2}$ values for both models but with a slightly better fit with the pseudo-second order model. Table 8 also compares the 
best kinetic fitting model of our bio-based composite to data from different adsorbents. Results show that pseudosecond order is generally the best fitting model for Chitosan/Cellulose adsorbents.

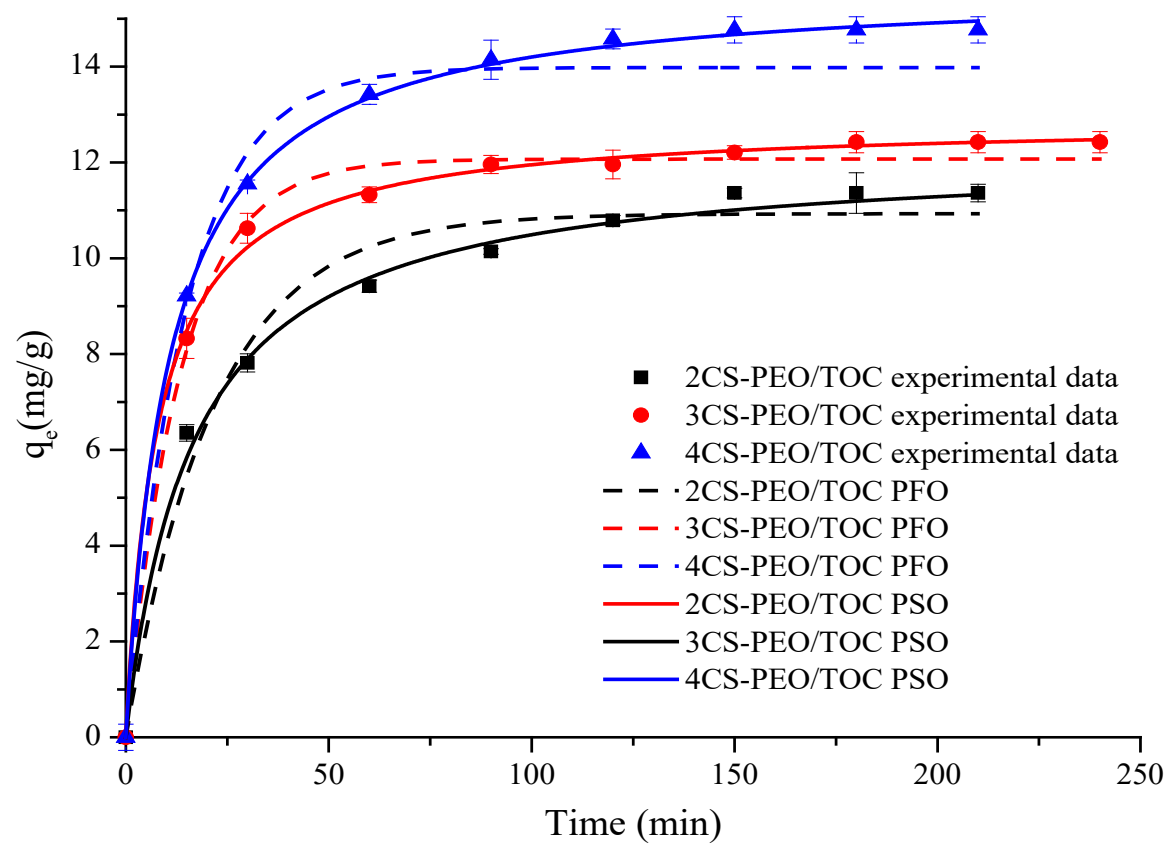

Fig. 9 Pseudo-first order and Pseudo-second order model of copper ions adsorption onto the xCS-PEO/TOC biocomposite

Table 7. Summary of kinetic models parameters for the adsorption of copper ions onto the $\mathrm{xCS}-\mathrm{PEO} / \mathrm{TOC}$ biocomposite

\begin{tabular}{lccccccccc} 
& \multicolumn{7}{c}{ Pseudo first order model } & \multicolumn{3}{c}{ Pseudo second order model } \\
\cline { 2 - 8 } & $\begin{array}{c}k_{1} \\
\left(\mathrm{~min}^{-1}\right)\end{array}$ & $\begin{array}{c}q_{e} \\
(\mathrm{mg} / \mathrm{g})\end{array}$ & $\mathrm{R}^{2}$ & $\mathrm{RMSE}$ & $\begin{array}{c}k_{2} \\
(\mathrm{~g} / \mathrm{g} \mathrm{min})\end{array}$ & $\begin{array}{c}q_{e} \\
(\mathrm{mg} / \mathrm{g})\end{array}$ & $\mathrm{R}^{2}$ & $\mathrm{RMSE}$ \\
2CS-PEO/TOC & 0.046 & 10.93 & 0.976 & 0.607 & 0.005 & 12.21 & 0.996 & 0.249 \\
3CS-PEO/TOC & 0.074 & 12.07 & 0.994 & 0.321 & 0.010 & 12.88 & 0.998 & 0.177 \\
4CS-PEO/TOC & 0.059 & 14.48 & 0.992 & 0.454 & 0.006 & 15.72 & 0.999 & 0.109 \\
\hline
\end{tabular}

To date, the chemical interaction between copper ions and chitosan is not know for sure. However, two models have been proposed: The bridge model and the pendant model. The first one presume that the metal ion is bound to several nitrogen and oxygen atoms from the same molecular chain or from different chains (Yaku et al. 1977). On the contrary, the pendant model consider that the metal ion is bound by only one nitrogen atom (Ogawa and Inukai 1987).

Table 8. Maximum adsorption capacity of $\mathrm{Cu}^{2+}$ of various chitosan/cellulose adsorbents

\begin{tabular}{cccc}
\hline Adsorbent & $\begin{array}{c}\text { Best kinetic } \\
\text { fitting model }\end{array}$ & $\begin{array}{c}\text { Maximum } \\
\text { adsorption capacity }\end{array}$ & Reference \\
\hline Chitosan/Cellulose blend hollow fibers & $\begin{array}{c}\text { Unlisted } \\
\text { Intraparticle } \\
\text { diffusion }\end{array}$ & $4.146 \mathrm{mg} / \mathrm{g}$ & (Liu and Bai 2005) \\
Chitosan/Cellulose hydrogel beads & $53.2 \mathrm{mg} / \mathrm{g}$ & (Li and Bai 2005) \\
N,O-carboxymethyl chitosan/Cellulose acetate & Unlisted & $72.60 \%$ & $\begin{array}{c}\text { (Boricha and } \\
\text { Murthy 2010) } \\
\text { (Thilagan et al. } \\
\text { Chitosan/Cellulose beads }\end{array}$ \\
$\begin{array}{c}\text { Pseudo-second } \\
\text { order }\end{array}$ & $43.95 \mathrm{mg} / \mathrm{g}$ & 2013) \\
\hline
\end{tabular}




\begin{tabular}{|c|c|c|c|}
\hline Chitosan/Cellulose acetate composite & Unlisted & $81.03 \%$ & $\begin{array}{l}\text { (Ghaee et al. } \\
\text { 2016) }\end{array}$ \\
\hline Electrospun chitosan/cellulose nanofibers & $\begin{array}{l}\text { Pseudo-second } \\
\text { order }\end{array}$ & $112.6 \mathrm{mg} / \mathrm{g}$ & (Phan et al. 2018) \\
\hline $\begin{array}{r}\text { Elec } \\
\text { Chitosan }\end{array}$ & $\begin{array}{l}\text { Pseudo-second } \\
\text { order }\end{array}$ & $484.06 \mathrm{mg} / \mathrm{g}, 90.58 \%$ & (Wang et al. 2018) \\
\hline $\begin{array}{l}\text { EDTA-Modified chitosan/Carboxymethyl cellulose } \\
\text { non porous mat }\end{array}$ & $\begin{array}{l}\text { Pseudo-second } \\
\text { order }\end{array}$ & $142.86 \mathrm{mg} / \mathrm{g}$ & $\begin{array}{l}\text { (Manzoor et al. } \\
\text { 2019) }\end{array}$ \\
\hline $\begin{array}{l}\text { Phosphorylated cellulose/electrospun chitosan } \\
\text { nanofibers }\end{array}$ & Un & $71.11 \%$ & $\begin{array}{l}\text { (Brandes et al. } \\
\text { 2020) }\end{array}$ \\
\hline $\begin{array}{l}\text { TEMPO-Oxidized cellulose/Electrospun chitosan- } \\
\text { Polyethylene oxide nanofibers }\end{array}$ & $\begin{array}{l}\text { Pseudo-second } \\
\text { order }\end{array}$ & $15.72 \mathrm{mg} / \mathrm{g}, 29.24 \%$ & This study \\
\hline
\end{tabular}

\section{Conclusions}

In this work, a xCS-PEO/TOC bio-based composite sorbent media was fabricated for the first time with a new environmentally friendly technique without the use of toxic solvents. The composite consists of an electrospun CSPEO nonwoven layer deposited on both sides of an oxidized cellulose (TOC) handsheet as a central core. The morphology studies showed that the micro/nano fibers have very well-defined structure and a uniform diameter distribution. Results showed that the TOC handsheet behaves as a reinforcing structure to improve the mechanical strength of electrospun nanofiber mats and provide good mechanical properties for the bio-based composite material. The effect of CS-PEO electrospinning time on TOC handsheet revealed that optimum strength and permeability of the materials were achieved after $2 \mathrm{~h}$ of electrospinning. Longer electrospinning time reduced significantly both properties. However, while not being at the same adsorption level of a CS-PEO nonwoven mat, the 2CS-PEO/TOC bio-based composite is the best compromise for optimization study. Further analysis will be conducted in order to investigate the biofouling, recycling and regeneration ability of this new sorbent composite media. Optimization of the permeability and adsorption capacity in multi-contaminant environment will also be carried out.

\section{References}

Abdullah N, Yusof N, Lau WJ, et al (2019) Recent trends of heavy metal removal from water/wastewater by membrane technologies. J Ind Eng Chem 76:17-38. https://doi.org/10.1016/j.jiec.2019.03.029

Abràmoff MD, Magalhães PJ, Ram SJ (2004) Image processing with imageJ. Biophotonics Int 11:36-41. https://doi.org/10.1201/9781420005615.ax4

Ahmad M, Ahmed S, Swami BL, Ikram S (2015) Adsorption of heavy metal ions: Role of chitosan and cellulose for water treatment. Int J Pharmacogn 2:280-289. https://doi.org/10.13040/IJPSR.0975-8232.IJP.2(6).280-89

Aliabadi M, Irani M, Ismaeili J, et al (2013) Electrospun nanofiber membrane of PEO/Chitosan for the adsorption of nickel, cadmium, lead and copper ions from aqueous solution. Chem Eng J 220:237-243. https://doi.org/10.1016/j.cej.2013.01.021

Amuda SO, Alade OA, Wang LK, Wang MS (2016) Toxicity, Sources, and Control of Copper (Cu), Zinc (Zn), Molybdenum (Mo), Silver (Ag), and Rare Earth Elements in the Environment. In: Remediation of Heavy Metals in the Environment. pp 1-26

Anastopoulos I, Kyzas GZ (2016) Are the thermodynamic parameters correctly estimated in liquid-phase adsorption phenomena? J Mol Liq 218:174-185. https://doi.org/10.1016/j.molliq.2016.02.059

Aquino RR, Tolentino MS, Amen SCS, et al (2018) Preparation of cellulose acetate blended with chitosan nanostructured membrane via electrospinning for $\mathrm{Cd} 2+$ adsorption in artificial wastewater. IOP Conf Ser Earth Environ Sci 191:. https://doi.org/10.1088/1755-1315/191/1/012137

ASTM F316-03 (2019) Standard Test Methods for Pore Size Characteristics of Membrane Filters by Bubble Point and Mean Flow Pore Test. ASTM International, West Conshohocken, PA

Bideau B, Cherpozat L, Loranger E, Daneault C (2016) Conductive nanocomposites based on TEMPO-oxidized cellulose and poly(N-3-aminopropylpyrrole-co-pyrrole). Ind Crops Prod 93:136-141. https://doi.org/10.1016/j.indcrop.2016.06.003 
Boricha AG, Murthy ZVP (2010) Preparation of N,O-carboxymethyl chitosan/cellulose acetate blend nanofiltration membrane and testing its performance in treating industrial wastewater. Chem Eng J 157:393-400. https://doi.org/10.1016/j.cej.2009.11.025

Brandes R, Belosinschi D, Brouillette F, Chabot B (2019) A new electrospun chitosan/phosphorylated nanocellulose biosorbent for the removal of cadmium ions from aqueous solutions. J Environ Chem Eng 7:. https://doi.org/10.1016/j.jece.2019.103477

Brandes R, Brouillette F, Chabot B (2020) Phosphorylated cellulose/electrospun chitosan nanofibers media for removal of heavy metals from aqueous solutions. J Appl Polym Sci 1-16. https://doi.org/10.1002/app.50021

Cardenas Bates II, Loranger É, Chabot B (2020) Chitosan - PEO nanofiber mats for copper removal in aqueous solution using a new versatile electrospinning collector. SN Appl Sci. https://doi.org/10.1007/s42452-02003342-5

Chen PJ, Wang LK, Wang MS, et al (2017) Remediation of Heavy Metals in the Environment. New-York

Demirkan E, Avci T, Aykut Y (2018) Protease immobilization on cellulose monoacetate/chitosan-blended nanofibers. J Ind Text 47:2092-2111. https://doi.org/10.1177/1528083717720205

Devarayan K, Hanaoka H, Hachisu M, et al (2013) Direct electrospinning of cellulose-chitosan composite nanofiber. Macromol Mater Eng 298:1059-1064. https://doi.org/10.1002/mame.201200337

Diagboya PN, Olu-Owolabi BI, Zhou D, Han B-H (2014) Graphene oxide-tripolyphosphate hybrid used as a potent sorbent for cationic dyes. Carbon N Y 79:174-182. https://doi.org/10.1016/j.carbon.2014.07.057

Dragan E, Apopei Loghin DF, Cocarta AI (2014) Efficient sorption of Cu2+ by composite chelating sorbents based on potato starch- graft -polyamidoxime embedded in chitosan beads. ACS Appl Mater Interfaces 6:1657716592. https://doi.org/dx.doi.org/10.1021/am504480q

Du J, Hsieh Y Lo (2009) Cellulose/chitosan hybrid nanofibers from electrospinning of their ester derivatives. Cellulose 16:247-260. https://doi.org/10.1007/s10570-008-9266-9

El Miri N, Abdelouahdi K, Zahouily M, et al (2015) Bio-nanocomposite films based on cellulose nanocrystals filled polyvinyl alcohol/chitosan polymer blend. J Appl Polym Sci 132:1-13. https://doi.org/10.1002/app.42004

Gerente C, Lee VKC, Le Cloirec P, McKay G (2007) Application of chitosan for the removal of metals from wastewaters by adsorption - Mechanisms and models review. Crit Rev Environ Sci Technol 37:41-127. https://doi.org/10.1080/10643380600729089

Ghaee A, Shariaty-Niassar M, Barzin J, et al (2016) Preparation of chitosan/cellulose acetate composite nanofiltration membrane for wastewater treatment. Desalin Water Treat 57:14453-14460. https://doi.org/10.1080/19443994.2015.1068228

Goetz LA, Jalvo B, Rosal R, Mathew AP (2016) Superhydrophilic anti-fouling electrospun cellulose acetate membranes coated with chitin nanocrystals for water filtration. J Memb Sci 510:238-248. https://doi.org/10.1016/j.memsci.2016.02.069

H.P.S AK, Saurabh CK, A.S. A, et al (2016) A review on chitosan-cellulose blends and nanocellulose reinforced chitosan biocomposites: Properties and their applications. Carbohydr Polym 150:216-226. https://doi.org/10.1016/j.carbpol.2016.05.028

Islam MT, Alam MM, Patrucco A, et al (2014) Preparation of nanocellulose: A review. AATCC J Res 1:17-23. https://doi.org/10.14504/ajr.1.5.3

Istirokhatun T, Rokhati N, Nurlaeli D, et al (2017) Characteristics, biofouling properties and filtration performance of cellulose/chitosan membranes. J Environ Sci Technol 10:56-67. https://doi.org/10.3923/jest.2017.56.67

Jabur AR, Abbas LK, Moosa SA (2016) Fabrication of electrospun chitosan/nylon 6 nanofibrous membrane toward metal ions removal and antibacterial effect. Adv Mater Sci Eng 2016:. https://doi.org/10.1155/2016/5810216

Jalvo B, Mathew AP, Rosal R (2017) Coaxial poly(lactic acid) electrospun composite membranes incorporating cellulose and chitin nanocrystals. J Memb Sci 544:261-271. https://doi.org/10.1016/j.memsci.2017.09.033

Jiaping Paul Chen, Wang LK, Wang M-HS, et al (2016) Removal of Heavy Metals by Low-Cost Adsorption Materials. In: Remediation of Heavy Metals in the Environment. pp 137-170 
Jin Y, Edler KJ, Marken F, Scott JL (2014) Voltammetric optimisation of TEMPO-mediated oxidations at cellulose fabric. Green Chem 16:3322-3327. https://doi.org/10.1039/c4gc00306c

Jradi K, Bideau B, Chabot B, Daneault C (2012) Characterization of conductive composite films based on TEMPOoxidized cellulose nanofibers and polypyrrole. J Mater Sci 47:3752-3762. https://doi.org/10.1007/s10853-011$6226-9$

Karim Z, Mathew AP, Grahn M, et al (2014) Nanoporous membranes with cellulose nanocrystals as functional entity in chitosan: Removal of dyes from water. Carbohydr Polym 112:668-676. https://doi.org/10.1016/j.carbpol.2014.06.048

Lakhdhar I, Belosinschi D, Mangin P, Chabot B (2016) Development of a bio-based sorbent media for the removal of nickel ions from aqueous solutions. J Environ Chem Eng 4:3159-3169. https://doi.org/https://doi.org/10.1016/j.jece.2016.06.026

Li H, Zhu C, Xue J, et al (2017) Enhancing the mechanical properties of electrospun nanofiber mats through controllable welding at the cross points. Macromol Rapid Commun 38:1-5. https://doi.org/10.1002/marc.201600723

Li N, Bai R (2005) Copper adsorption on chitosan-cellulose hydrogel beads: Behaviors and mechanisms. Sep Purif Technol 42:237-247. https://doi.org/10.1016/j.seppur.2004.08.002

Li Q, Wang X, Lou X, et al (2015) Genipin-crosslinked electrospun chitosan nanofibers: Determination of crosslinking conditions and evaluation of cytocompatibility. Carbohydr Polym 130:166-174. https://doi.org/10.1016/j.carbpol.2015.05.039

Li Z, Ma J, Li R, et al (2018) Fabrication of a blood compatible composite membrane from chitosan nanoparticles, ethyl cellulose and bacterial cellulose sulfate. RSC Adv 8:31322-31330. https://doi.org/10.1039/c8ra05536j

Li Z, Mei S, Dong Y, et al (2019) High Efficiency Fabrication of Chitosan Composite Nanofibers with Uniform Morphology via Centrifugal Spinning. Polymers (Basel) 11:1550. https://doi.org/10.3390/polym11101550

Liu C, Bai R (2005) Preparation of chitosan/cellulose acetate blend hollow fibers for adsorptive performance. J Memb Sci 267:68-77. https://doi.org/10.1016/j.memsci.2005.06.001

Liu P, Garrido B, Oksman K, Mathew AP (2016a) Adsorption isotherms and mechanisms of Cu(ii) sorption onto TEMPO-mediated oxidized cellulose nanofibers. RSC Adv 6:107759-107767. https://doi.org/10.1039/c6ra22397d

Liu P, Oksman K, Mathew AP (2016b) Surface adsorption and self-assembly of Cu(II) ions on TEMPO-oxidized cellulose nanofibers in aqueous media. J Colloid Interface Sci 464:175-182. https://doi.org/10.1016/j.jcis.2015.11.033

Ma H, Burger C, Hsiao BS, Chu B (2012) Nanofibrous microfiltration membrane based on cellulose nanowhiskers. Biomacromolecules 13:180-186. https://doi.org/10.1021/bm201421g

Manzoor K, Ahmad M, Ahmad S, Ikram S (2019) Synthesis, Characterization, Kinetics, and Thermodynamics of EDTA-Modified Chitosan-Carboxymethyl Cellulose as Cu(II) Ion Adsorbent. ACS Omega 4:17425-17437. https://doi.org/10.1021/acsomega.9b02214

Mao H, Wei C, Gong Y, et al (2019) Mechanical and water-resistant properties of eco-friendly chitosan membrane reinforced with cellulose nanocrystals. Polymers (Basel) 11:. https://doi.org/10.3390/polym11010166

Mekahlia S, Bouzid B (2009) Chitosan-Copper (II) complex as antibacterial agent: synthesis, characterization and coordinating bond- activity correlation study. Phys Procedia 2:1045-1053. https://doi.org/10.1016/j.phpro.2009.11.061

Miao J, Pangule RC, Paskaleva EE, et al (2011) Lysostaphin-functionalized cellulose fibers with antistaphylococcal activity for wound healing applications. Biomaterials 32:9557-9567. https://doi.org/10.1016/j.biomaterials.2011.08.080

Morgado DL, Frollini E, Castellan A, et al (2011) Biobased films prepared from $\mathrm{NaOH} /$ thiourea aqueous solution of chitosan and linter cellulose. Cellulose 18:699-712. https://doi.org/10.1007/s10570-011-9516-0

Muthu Kumar TS, Senthil Kumar K, Rajini N, et al (2019) A comprehensive review of electrospun nanofibers: Food and packaging perspective. Compos Part B Eng 175:107074. 
https://doi.org/10.1016/j.compositesb.2019.107074

Ogawa K, Inukai S (1987) X-Ray diffraction study of sulfuric, nitric, and halogen acid salts of chitosan. Carbohydr Res 160:425-433. https://doi.org/10.1016/0008-6215(87)80328-2

Onyianta AJ, Dorris M, Williams RL (2017) Aqueous morpholine pre-treatment in cellulose nanofibril (CNF) production: comparison with carboxymethylation and TEMPO oxidisation pre-treatment methods. Cellulose 25:1047-1064. https://doi.org/10.1007/s10570-017-1631-0

Paquin M, Loranger É, Hannaux V, et al (2013) The use of Weissler method for scale-up a kraft pulp oxidation by TEMPO-mediated system from a batch mode to a continuous flow-through sonoreactor. Ultrason Sonochem 20:103-108. https://doi.org/10.1016/j.ultsonch.2012.08.007

Park TJ, Jung YJ, Choi SW, et al (2011) Native chitosan/cellulose composite fibers from an ionic liquid via electrospinning. Macromol Res 19:213-215. https://doi.org/10.1007/s13233-011-0315-0

Phan D-N, Lee H, Huang B, et al (2018) Fabrication of electrospun chitosan/cellulose nanofibers having adsorption property with enhanced mechanical property. Cellulose 26:1781-1793. https://doi.org/10.1007/s10570-0182169-5

Ranade V V, Bhandari V (2017) Industrial Wastewater Treatment Technologies, Recycling, and Reuse. Elsevier

Ridolfi DM, Lemes AP, de Oliveira S, et al (2017) Electrospun poly(ethylene oxide)/chitosan nanofibers with cellulose nanocrystals as support for cell culture of 3T3 fibroblasts. Cellulose 24:3353-3365. https://doi.org/10.1007/s10570-017-1362-2

Salihu G, Goswami P, Russell S (2012) Hybrid electrospun nonwovens from chitosan/cellulose acetate. Cellulose 19:739-749. https://doi.org/10.1007/s10570-012-9666-8

Sarkar S, Adhikari S (2018) Adsorption Technique for Removal of Heavy Metals from Water and Possible Application in Wastewater-Fed Aquaculture. In: Jana B., Mandal, R., Jayasankar P (ed) Wastewater Management Through Aquaculture. Springer, Singapur, pp 232-251

Sehaqui H, de Larraya UP, Liu P, et al (2014) Enhancing adsorption of heavy metal ions onto biobased nanofibers from waste pulp residues for application in wastewater treatment. Cellulose 21:2831-2844. https://doi.org/https://doi.org/10.1007/s10570-014-0310-7

Sigma Aldrich I (2020) IR Spectrum Table \& Chart. https://www.sigmaaldrich.com/technicaldocuments/articles/biology/ir-spectrum-table.html\#ir-table-by-compound. Accessed 27 Apr 2020

Somsap J, Kanjanapongkul K, Chancharoonpong C, et al (2019) Antimicrobial activity of edible electrospun chitosan/cellulose acetate/gelatin hybrid nanofiber mats incorporating eugenol. Curr Appl Sci Technol 19:235247. https://doi.org/10.14456/cast.2019.20

Soni B, Hassan EB, Schilling MW, Mahmoud B (2016) Transparent bionanocomposite films based on chitosan and TEMPO-oxidized cellulose nanofibers with enhanced mechanical and barrier properties. Carbohydr Polym 151:779-789. https://doi.org/10.1016/j.carbpol.2016.06.022

Spaic M, Small DP, Cook JR, Wan W (2014) Characterization of anionic and cationic functionalized bacterial cellulose nanofibres for controlled release applications. Cellulose 21:1529-1540. https://doi.org/10.1007/s10570-014-0174-x

Szczesny SE, Driscoll TP, Tseng HY, et al (2017) Crimped Nanofibrous Biomaterials Mimic Microstructure and Mechanics of Native Tissue and Alter Strain Transfer to Cells. ACS Biomater Sci Eng 3:2869-2876. https://doi.org/10.1021/acsbiomaterials.6b00646

Szymańska-Chargot M, Chylińska M, Pertile G, et al (2019) Influence of chitosan addition on the mechanical and antibacterial properties of carrot cellulose nanofibre film. Cellulose 26:9613-9629. https://doi.org/10.1007/s10570-019-02755-9

Teow YH, Kam LM, Mohammad AW (2018) Synthesis of cellulose hydrogel for copper(II) ions adsorption. J Environ Chem Eng 6:4588-4597. https://doi.org/10.1016/j.jece.2018.07.010

Tetala KKR, Stamatialis DF (2013) Mixed matrix membranes for efficient adsorption of copper ions from aqueous solutions. Sep Purif Technol 104:214-220. https://doi.org/https://doi.org/10.1016/j.seppur.2012.11.022

Thilagan J, Gopalakrishnan S, Kannadasan T (2013) A Comparative Study On Adsorption Of Copper (Ii) Ions In 
Aqueous Solution By; (A) Chitosan Blended With Cellulose And Cross Linked By Formaldehyde, (B) Chitosan Immobilised On Red Soil, (C) Chitosan Reinforced By Banana Stem Fibre. Int J Appl Eng Technol 2:10431054

Tian Y, Wu M, Liu R, et al (2011) Electrospun membrane of cellulose acetate for heavy metal ion adsorption in water treatment. Carbohydr Polym 83:743-748. https://doi.org/10.1016/j.carbpol.2010.08.054

Vardhan KH, Kumar PS, Panda RC (2019) A review on heavy metal pollution, toxicity and remedial measures: Current trends and future perspectives. J Mol Liq 290:111197. https://doi.org/10.1016/j.molliq.2019.111197

Waheed S, Ahmad A, Khan SM, et al (2014) Synthesis, characterization, permeation and antibacterial properties of cellulose acetate/polyethylene glycol membranes modified with chitosan. Desalination 351:59-69. https://doi.org/10.1016/j.desal.2014.07.019

Wang D, Cheng W, Yue Y, et al (2018) Electrospun cellulose nanocrystals/chitosan/polyvinyl alcohol nanofibrous films and their exploration to metal ions adsorption. Polymers (Basel) 10:. https://doi.org/10.3390/polym10101046

Weng R, Chen L, Lin S, et al (2017) Preparation and characterization of antibacterial cellulose/chitosan nanofiltration membranes. Polymers (Basel) 9:1-13. https://doi.org/10.3390/polym9040116

Weng R, Huang X, Liao D, et al (2020) A novel cellulose/chitosan composite nanofiltration membrane prepared with piperazine and trimesoyl chloride by interfacial polymerization. RSC Adv 10:1309-1318. https://doi.org/10.1039/c9ra09023a

Xue J, Wu T, Dai Y, Xia Y (2019) Electrospinning and electrospun nanofibers: Methods, materials, and applications. Chem Rev 119:5298-5415. https://doi.org/10.1021/acs.chemrev.8b00593

Yadav M, Behera K, Chang YH, Chiu FC (2020) Cellulose nanocrystal reinforced chitosan based UV barrier composite films for sustainable packaging. Polymers (Basel) 12:. https://doi.org/10.3390/polym12010202

Yaku F., Muraki E., Tsushiya K., et al (1977) Chitosan-metal complexes and their function. Cellul Chem Technol 11:

Yang J, Kwon GJ, Hwang K, Kim DY (2018) Cellulose-chitosan antibacterial composite films prepared from LiBr solution. Polymers (Basel) 10:1-7. https://doi.org/10.3390/polym10101058

Yezer I, Demirkol DO (2020) Cellulose acetate-chitosan based electrospun nanofibers for bio-functionalized surface design in biosensing. Cellulose 27:10183-10197. https://doi.org/10.1007/s10570-020-03486-y

Zhang L, Zeng Y, Cheng Z (2016) Removal of heavy metal ions using chitosan and modified chitosan: A review. J Mol Liq 214:175-191. https://doi.org/10.1016/j.molliq.2015.12.013

Zhang Y, Lin S, Qiao J, et al (2018) Malic acid-enhanced chitosan hydrogel beads (mCHBs) for the removal of Cr(VI) and $\mathrm{Cu}(\mathrm{II})$ from aqueous solution. Chem $\quad$ Eng J 353:225-236. https://doi.org/https://doi.org/10.1016/j.cej.2018.06.143

Zhou C, Chu R, Wu R, Wu Q (2011) Electrospun polyethylene oxide/cellulose nanocrystal composite nanofibrous mats with homogeneous and heterogeneous microstructures. Biomacromolecules 12:2617-2625. https://doi.org/10.1021/bm200401p

Zhu C, Liu P, Mathew AP (2017) Self-Assembled TEMPO Cellulose Nanofibers: Graphene Oxide-Based Biohybrids for Water Purification. ACS Appl Mater Interfaces 9:21048-21058. https://doi.org/10.1021/acsami.7b06358 